Article

\title{
Becoming Citizen: Spatial and Expressive Acts when Strangers Move In
}

\author{
Peter Kærgaard Andersen ${ }^{1, *}$, Lasse Mouritzen ${ }^{1}$ and Kristine Samson ${ }^{2}$ \\ 1 Jamboy Art/Research collective, 2200 Copenhagen, Denmark; E-Mails: Kaergaard.peter@gmail.com (P.K.A), \\ Lasse.Mouritzen@gmail.com (L.M.) \\ 2 Department of Communication and Art, Visual Culture and Performance Studies, Roskilde University, 4000 Roskilde, \\ Denmark; E-Mail: ksamson@ruc.dk \\ * Corresponding author
}

Submitted: 31 March 2018 | Accepted: 5 June 2018 | Published: 30 August 2018

\begin{abstract}
This article examines the conditions and expressions of how refugees in Denmark become citizens. Through visual and collaborative ethnographic fieldwork, which took place during 2017, the case study follows the everyday life of an Eritrean community living in a former retirement home in the town of $\mathrm{H} \emptyset$ rsholm. The article investigates how becoming citizen can be understood as mediatised, spatial and expressive negotiations between the refugees and the local society. We look at the conditions of becoming citizen through the local framing of the Eritrean community-understood as political, social, cultural and material framing conditions. We draw on Engin Isin's concept of performative citizenship (Isin, 2017), and we suggest how everyday life and becoming potentially hold the capacity to re-formulate and add to the understanding of citizenship. We suggest that becoming citizen is not merely about obtaining Danish citizenship and civic rights nor tantamount with settling down. On the contrary, the analysis shows that becoming citizen is a process of expressed and performed desires connected to global becomings beyond the sedentary citizenship, and therefore holds capacity for transforming and diversifying the notion of citizenship.
\end{abstract}

\section{Keywords}

becoming; citizenship; cultural encounters; globalisation; performative citizenship

\section{Issue}

This article is part of the issue "Migration, Boundaries and Differentiated Citizenship", edited by Terry Wotherspoon (University of Saskatchewan, Canada).

(C) 2018 by the authors; licensee Cogitatio (Lisbon, Portugal). This article is licensed under a Creative Commons Attribution 4.0 International License (CC BY).

\section{Introduction}

In an upper-class residential area in Hørsholm, north of Copenhagen in Denmark, a group of Eritrean refugees was housed in an out of use retirement home after obtaining temporary asylum in Denmark in 2016. Recognised by the local citizens of $\mathrm{H} \varnothing \mathrm{rsholm}$ as the 'refugees of the retirement home', the Eritrean community made their life on the threshold of society and citizenship. Exploring the material and social conditions associated with processes of becoming citizen, we address how the Eritrean community is organised from a sedentary narration of the local society, and how they simultaneously reenact the conditions and contribute new practiced and performed ways of becoming citizen.
As noted by Gilles Deleuze and Félix Guattari: "History is always written from the sedentary point and in the name of unitary State apparatus, at least a possible one, even when the topic is nomads" (Deleuze \& Guattari, 1987, p. 23). Parallel to the nomadic thought in A Thousand Plateaus, Engin Isin recently defined citizenship from the perspective of the mobile and nomadic, regarding "mobile peoples as a norm rather than an exception" (Isin, 2018, p. 115). He argues that we must look into how mobile peoples constitute themselves as political subjects "not in bounded territories but through transversal figurations" (Isin, 2018, p. 121). In this article, we will reorient the perspective from looking into the fixed and settled forms and territories of the state, and instead follow the transversal configura- 
tions and the nomadic expressions defining mobile peoples. Following Isin, Hamann and Yurdakul (2018) argue that "migrants and refugees contest and transform dominant notions of the nation-state, state control, national sovereignty, citizenship, and participation" (Hamann \& Yurdakul, 2018, p. 110). Informed by this insight, the analysis of this article is twofold. On one hand, we ask how the forms of rights-based citizenship, offered by the state and in this case the municipality of $\mathrm{H} \emptyset \mathrm{rsholm}$, condition the becoming citizen. On the other hand, we ask how the expressive enactments carried out in everyday life by the Eritrean community perform other ways of becoming citizen. In this context, we see the local conditions and the performed expressions not as contradictory oppositions, but rather as processes of constant de-territorialisations and re-territorialisations. In the following section, we argue that processes of deterritorialisation and re-territorialisation are part of an increasingly mobile world and form an analytical framework suitable for bringing forth the expressive citizenship of mobile peoples.

\section{The Global Movements of De- and Re-Territorialisation}

In mobility research, globalisation has come to mean a new mobilities paradigm, in which mobility is the overall defining notion (Cresswell, 2006; Sheller \& Urry, 2006). In the mobilities paradigm, global travellers as asylum seekers, international students, terrorists, holidaymakers, businesspeople, sports stars, refugees and backpackers all share the same global experience of mobilities, being constantly on the move. Mobility gives rise to global everyday encounters that contest social norms and identities bound to the nation state and its politics. In a mobility paradigm, the definitions and understanding of migrants' citizenship largely deal with a shift from the rights associated with the nation state to globalised expressions. It has been argued in several disciplines how globalisation de-territorialises the nation state, its politics, symbols and social identities (Appadurai, 1997, 2006; Papastergiadis, 2000; Tomlinson, 1999). However, globalisation does not entail an arbitrary circulation; instead movements are channelled and regulated through national and transnational interests and networks (Lash \& Urry, 1994). In a similar vein, Deleuze and Guattari (1987) see how the narrative of nation state has been formed from a sedentary point of view by exclusion or organisation of the nomadic. The fundamental contradiction, which have formed the societal constitution, is thus the nomadic movement versus the settled life (Diken \& Laustsen, 2003). Here, movement has created our territories, and transcendence has created the borders and the law (Bell, 2010; Deleuze \& Guattari, 1987; Diken \& Laustsen, 2003). In this sense, globalisation and its diverse forms of mobilities can be understood as a constant and mutual exchange between de-territorialisations and re-territorialisations.
Also, the exchanges between de-territorialisations and re-territorialisations allow us to say that the local is constantly created through the process of everyday implementation of global elements-and vice versa. Components from different environments are detached from their initial surroundings and given associations as they re-territorialise in new forms. In these complex processes, places and cultural identity are dissolved, but are at the same time re-defined in re-territorialisations (Deleuze \& Guattari, 1987; Reestorff, 2017).

Globalisation changes national identities and places, but also enables fluid relationships in between nation state and an increasingly global mobility. Globalisation and its mobilities become "the subject of negotiations in which the relationship between the nation state, cultural identity and geography might be reconfigured or reterritorialised" (Reestorff, 2017, p. 11). Therefore, globalisation and associated processes of de-territorialisation and re-territorialisation represent a dynamic framework that enables us to grasp citizenship as a process of becoming. Following Isin and recent citizenship studies (Isin, 2012, 2017), we argue that the stability and identity of citizenship is contested; therefore, citizenship can be regarded from mobile and nomad perspectives of migrant and mobile peoples as well as from those of more settled populations (Isin, 2018). This enables viewing performed forms of citizenship as holding the potential to redefine and transform formal citizenship defined by nation states. If the world is increasingly defined by mobility, we must approach citizenship, not merely through juridical rights, but as embodied, practiced and performed acts of what it means to be a citizen. (Appadurai \& Holston, 1996; Isin, 2012, 2017; Isin \& Turner, 2002). In this sense, citizenship is not a formal right that you acquire; rather it is a process of becoming, involving a variety of cultural, social and spatial expressions.

Moreover, the definition of a migrant can be redefined in terms of mobilities. As Isin suggests, to see "mobile peoples as a norm rather than an exception and as political subjects rather than subject peoples" (Isin, 2018, p. 115). The migrant is no longer a figure defined by belonging to a national territory, but rather by the mobility and ability to perform forms of citizenships (Isin, 2017). In contrast to citizenship as a legal institution, which governs who may and may not act as a subject of rights in the nation state, Isin's notion of 'performative citizenship' welcomes five overlapping senses of how citizenship is negotiated and practiced (Isin, 2017). Whereas Isin's first definitions of performative citizenships engage with the political and social struggles over who may and may not act as a subject of rights, we are particularly interested in his fourth and fifth definitions, looking into how "people enact citizenship by exercising, claiming, and performing rights and duties, and...when people enact citizenship they creatively transform its meanings and functions" (Isin, 2017, p. 501). In this sense, we see the Eritrean community not merely as refugees, but as 'mobile peoples', "who have become objects of government" (Isin, 
2018, p. 116), but practice their own forms of expressive 'becomings'. As mobile peoples in the sense of nomads, they have the capacity to de-territorialise local identities and places.

Our interest in this article is to depict and unfold the expressive and performed modes of becoming citizen. Seeking to bring forth the complex production of subjectivity related to mobile peoples, we look into how the community inhabits and negotiates the local conditions in $\mathrm{H} \varnothing \mathrm{rsholm}$. For instance, Holston notes how "residents come to understand their basic needs in terms of their inhabiting the city, suffering it, building their daily lives in it, and making its cityscape, history, and politics" (Holston, 2011, p. 337). In this context, citizenship is understood as spatial re-territorialisations, relating to how residents claim the right to the city. Whereas we do not directly address the refugees' right to the city as a right in public space, we seek to understand the everyday practices of, for instance, inhabiting the local environment and making everyday cultural, spatial and embodied expressions. The acts of inhabiting are often complex and heterogeneous. Roger Bromley argues that the post-migrant is a figure of bricolage, which practices cultural belonging, but without anchorage in an original culture: "They may start out from a 'minority' position, from the margins, but develop within new fields of reference to a point of being part of, for example, British culture" (Bromley, 2017 , p. 37). The notion of becoming citizen is closely related to practices and acts that are not discursive utterances, but must be understood as a form of local body politics. According to George Kandylis:

Immigrants in Athens invent and perform ways to participate in the people as the body politics at the local level. To wonder about that is of course to consider citizenship as a process of repetitive becoming through acts rather than as merely a condition of being and/or as a given status. (Kandylis, 2017, p. 469)

Investigating performative acts and embodied politics challenges the discursive hierarchy in social research. In the following, we outline how we have employed visual and collaborative methodologies in an effort to capture the embodied and performative expressions.

\section{Materialising Acts of Citizenship: A Visual and Collaborative Methodology}

The following case study draws on visual and collaborative ethnographic methods through a project that took place in the former retirement home from February to September 2017. Whereas recent studies look into how citizenship is spatially and culturally performed in public life with the city as stage (Kandylis, 2017; Lelandais, 2013), we primarily look into the private spheres and the urban back-stages of everyday life. The Eritrean community consists of a diverse group of mixed ages, genders and backgrounds. They were all given a 5-year permit of residence in Denmark and had begun formal integration programs entailing language classes, internships, educations and job programs. The visual material was supplemented by ethnographic participatory observations, and document analysis looking into the local newspaper's coverage of the temporary housing of refugees. The ethnographic approach had a spatial and embodied dimension as it was carried out as collaborative filmmaking organised at a filmmaking office. It was established in the former retirement home with consent from the Eritrean community. The purpose of situating the filmmaking office among the residents was to share and co-create the visual material, and to be part of everyday situations. Our agreement with the community was a common wish to establish a platform of sharing cultures and connecting to society, meaning to co-create a film that could represent the Eritrean community and allow research on cultural encounters and temporary refugee housing in Denmark. Making the film allowed us to look into how spatial practices and expressions were enacted on a daily basis, and how these practices met the framing conditions of the municipality of $\mathrm{H} \varnothing \mathrm{rsholm}$. In the analysis, we also draw on ethnographic participatory observation conducted with a Syrian community living in vicinity of the former retirement home.

Specifically, our methods draw on visual and sensory ethnography (Pink, 2011, 2009), and are informed by recent social art practices, where for instance film production and ethnographic methods are increasingly applied (Bishop, 2012; Kester, 2011). The visual ethnographic approach consisted of both observing visual and sensory actions and practices, but also collaborating in the production of new representation through filmmaking (Pink, 2011). The quotes and field notes presented in this article are part of the visual ethnographic field research, where filmmaking can be seen as a bricolage of scientific methods that engage everyday day practices increasingly acted out through various use of media. The empirical material consists of observations, informal conversations, situations and interactions in the home of the Eritrean community.

As argued by Deleuze and Guattari (1987, pp. 280281): "Movement has an essential relation to the imperceptible; it is by nature imperceptible. Perception can grasp movement only as the displacement of a moving body or the development of a form". Taking into consideration the difficulty in representing movement and the becoming citizen as acts, we do not see the empirical material as documentation. Rather, filmmaking can be understood as part of the mediated and performing acts of the Eritrean community. The quotes, field notes and media examples are productions of an ethnography that "rather than a method for the collection of data...is a process of creating and representing knowledge (about society, culture and individuals) that is based on ethnographers' own experiences" (Pink, 2011, pp. 21-39). With the filmmaking office, we established a collaborative space and mutual relations over time. The community 
became more engaged in the filmmaking, and we as researchers became more engaged with the everyday life of the community. Furthermore, the filmmaking spurred common discussions about experiences and sensitivities, as residents from the community recorded parts of the film. Likewise, the material and its possible meanings were discussed during the process. The final film product (21 minutes) is a poetic description of the life as it unfolds in the community, followed by a voiceover in Tigrinya. The editing of scenes and the application of the voiceover was carried out with recurrent discussions in-and screenings with-the community. The film was shown at the local library in order to welcome further elaborations on how citizenship is performed and practiced in the local society of $\mathrm{H} \varnothing \mathrm{rsholm}$.

\section{Mediatised Framing Conditions}

As noted by Isin (2018), all acts are acts performed under a description. "If new descriptions come into being, new possibilities for action come into being as a consequence" (Hacking, 2002, p. 108; Isin, 2017). In this sense, the act of naming a people is an act of "making up a people" (Isin, 2018, p. 118). When people act, they interact with descriptions, and this creates a looping effect where descriptions acquire performative force.

If we look at the description of the refugee, we see that a refugee is defined as someone being forced to leave his or her country in order to escape war, persecution or disasters. In this definition, the refugee emerges essentially as a figure of escape. We consider this framing inadequate as it loops people in a singular trajectory of moving away from something. In the movement away from their country, they become defined as stateless people or a people without a geography. The mobile peoples have always been described and understood from a sedentary point of view (Deleuze \& Guattari, 1987; Diken \& Laustsen, 2003; Isin, 2018). Being disconnected from a geography or a territory, these people similarly lose their spatial constitution and engagement with their own history and belonging. Following Isin, we might say that they become 'a people of escape' or 'a people without a state', differentiated from 'the people', like a part that is disconnected from the whole (Isin, 2018).

We suggest, concurrent to Isin, that mobile peoples are the norm rather than the exception, and that movement of 'people' is never a one-way process (Isin, 2018, pp. 115-116), such as leaving one state and entering another. Instead, mobile peoples can be understood in terms of processes of becoming, involving complex and heterogeneous forms of expressions, for instance enactments of local cultures merged with global media culture and symbols. As argued by Bromley (2017), one of the issues when analysing expressions of post-migration, is the notion of "the presumed commonality, or identity, between always existing national subjects, a fundamental aspect of subjectivity at the level of the symbolic, the cultural, the unconscious" (Bromley, 2017, p. 38).
In this light, we wish to challenge the simplified definition of the refugee as a figure of escape-a commonality constructed from the viewpoint of a national subject. This commonality tends to lead to our understanding of and relation to the refugee as a one-dimensional figure of escape and fear, therefore deprived of his or her desire to connect with and enter a certain territory and community. In this context, the discursive naming of mobile peoples plays a major part in creating imaginaries and in how to control movement. An obvious example can be found in the Danish media discourse. In reporting on the refugee situation in 2015-2016, the notions of the 'refugee stream' (flygtningestrømmen), and the 'refugee crisis' were repeated images used to frame mobile peoples. Similar to Reestorff (2017) and Stage (2011), we see how media play an important role as being representative of the nation state. "News media simply promote an understanding of a cultural clash and the media themselves as defenders of the 'Danes'" (Reestorff, 2017, p. 235). In the framing, the Danish media submits metaphors of the refugee as a faceless stream of otherness; a natural force or endless disaster. These metaphors of the refugee seem to resonate in the everyday perceptions of mobile peoples. Following Deleuze and Guattari and their understanding of 'refrains' (Deleuze \& Guattari, 1987; Guattari, 2000), we can argue that the mediated and politically framed discourses of the refugee are central to the way territories operate and take form. When discourses are repeated, they constitute a refrain. They become a collection of imagery that repeatedly defines and gives identity to a place, a group and a culture. For instance, the repetition of the metaphor of the refugee stream serves to illustrate a threat to the national border. In this way, we argue that national conditions, such as the media discourses, are a condition of framing mobile peoples (Isin, 2018), but in a similar vein, media and mediatisation also have the potential to de-territorialise and re-territorialise national identity as it smoothly travels beyond national borders and territories (Reestorff, 2017).

In the following sections, we look into local framing conditions and how the Eritrean community practices becoming citizen through expressive negotiations of existing refrains and local conditions. These performative acts have a connection to citizenship as well as a potential to transform it. We look into: 1) local framing conditions, 2) spatio-temporal and embodied practices, and 3) becoming, media and youth.

\section{Local Framing Conditions}

Belonging can be seen as personal, intimate feelings of being 'at home' in a place, but also as a discursive resource, which constructs, claims, justifies, or resists forms of socio-spatial inclusion/exclusion (Antonsich, 2010). This section attempts to identify various local spatial and expressive conditions in Hørsholm, thus defining a local sense of expression that constitutes a be- 
longing, which additionally frames the Eritrean community as otherness (see Figures 1 to 3 ).

The local spatial conditions cover the various sociomaterial and economic infrastructures existing in the local area. In the following, spatial conditions and expressions are understood as for instance the urban materiality, the housing structure and urban infrastructure, the aesthetic and sensory environment such as smells and sounds, local media, types of consumption, urban development projects and local policies. These elements play a part in the relation between the Eritrean community and local society by defining and categorising otherness through belonging to certain spatial conditions. One determining factor is the socio-economic status of $\mathrm{H} \varnothing \mathrm{rsholm}$ and the housing typology. As noted by a local citizen in relation to the Eritrean community:

But let's face it, they will never be able to live here. People saved up all their lives to buy a house here. $\mathrm{H} \varnothing \mathrm{rsholm}$ is the last step of the ladder, the last place to settle down and get a nice place to live.
From the quote, we understand how spatial conditions play an important role in how Eritrean community is received. In other words, this example shows that to navigate in a local society, you need to be able to perform certain spatial codes such as owning a house. Spatial expressiveness exists not only in the material surroundings, but also in cultural codes and consumption, thus framing processes of social becoming.

As illustrated in the quote above, the local citizens understand the neighbourhood through the expression of a socio-economic hierarchy, where belonging is the same as belonging to a specific exclusivity. The quote underlines that Eritrean community need to adapt to this identity, and at the same time accept that they will never become a real part of it. Likewise, the aforementioned nation state discourse of refugees as figures of escape becomes embedded in the local framing. As a citizen explains in the Hørsholm newspaper: "It almost seems like they are hiding from an airplane [krøbet i flyverskjul]. Like they are hiding from us" (Hørsholm Lokalavis, 2016). Here the quietness and invisibility, which could be ar-

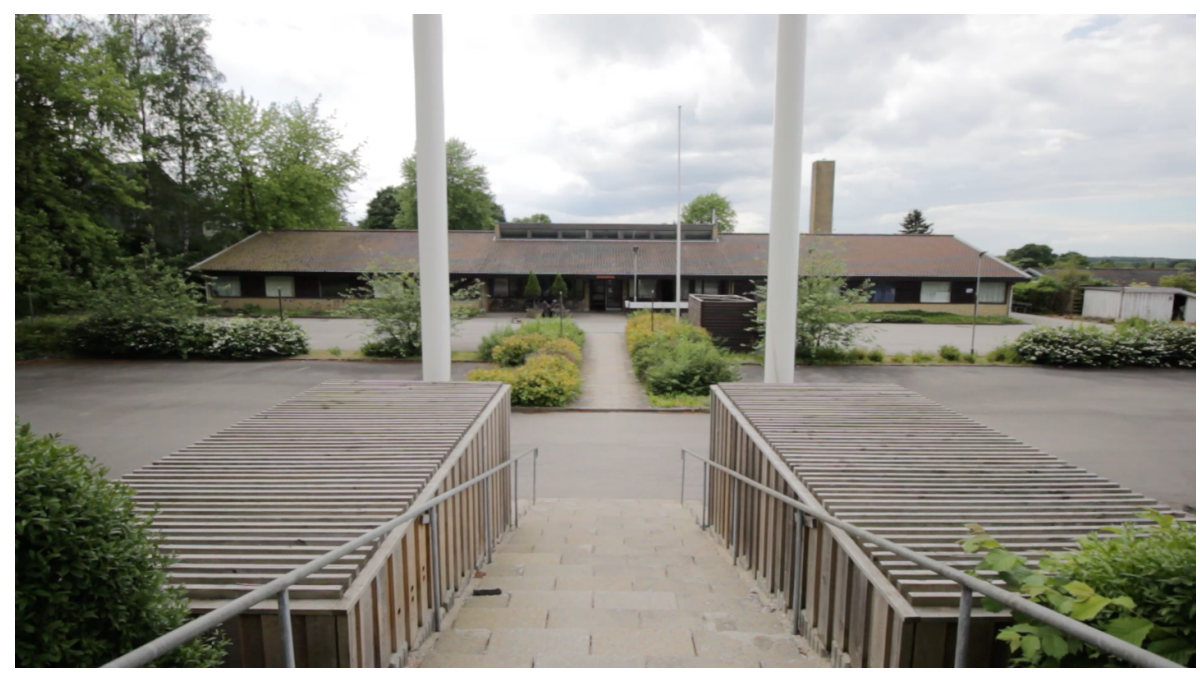

Figure 1. Former retirement home as seen from the street. May 2017.

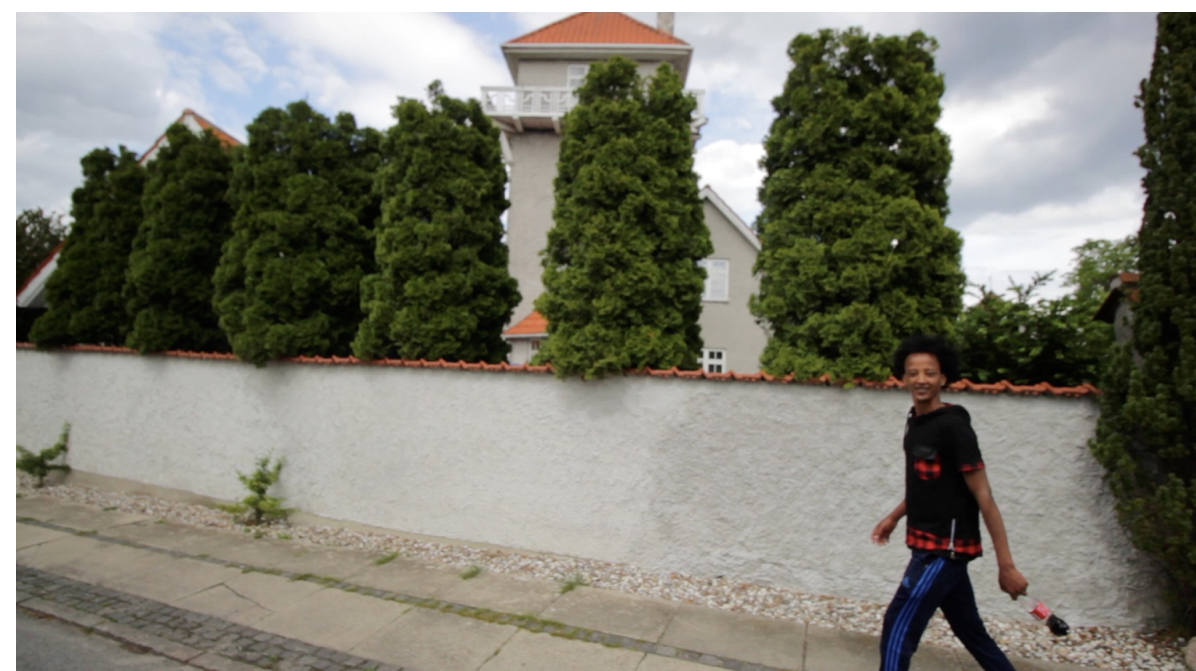

Figure 2. Passing a neighbouring house. May 2017. 


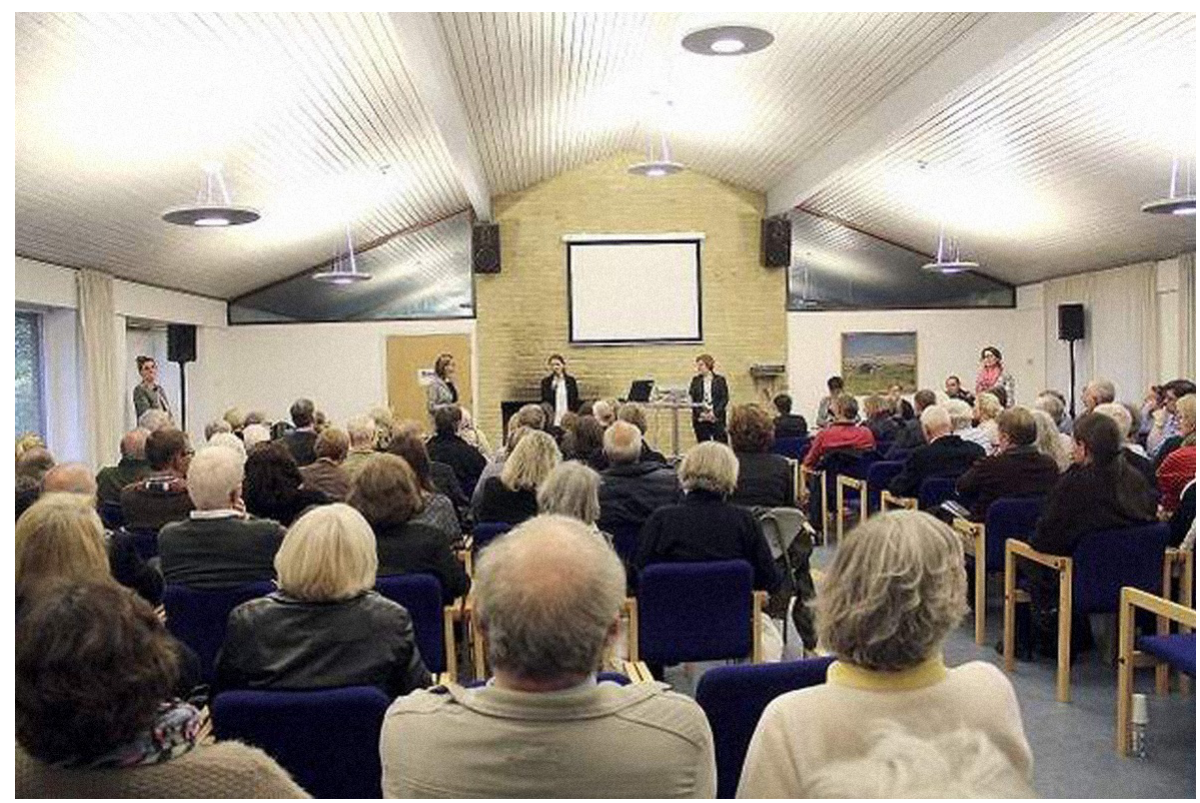

Figure 3. Public hearing at the former retirement home. May 2015, (Source: Hørsholm Lokalavis, 2015).

gued is a part of the urban typography of private plots, is perceived as a product of persecution, fear and escape; a logic that captures the movement of the refugee in one dimension away from society.

The urban planning process of housing new Eritrean residents in the former retirement home was accompanied by a public hearing and debate for local citizens. The purpose was to inform local citizens of the two years of refugee housing, and to consider the opinions of the neighbourhood. The public involvement marked one of the first encounters of difference in the neighbourhood, but on the foundation of an anticipated difference. The public hearing can be regarded as an example of grey urbanism, in which certain populations are allowed full participation whereas others are left out. In this sense, citizenship is made through an unequal distribution of access and services, based on social class or ethnicity (Yiftachel, 2006). Following Bromley this can be seen as a cogent reality where cultural difference becomes part of rationalising segregation (Bromley, 2017). As such, home belongings that draw lines of separations between cultures.

There is no hedge on the boundary from our house to Hannebjerg [the former retirement home]. We decided to put up a lath fence. We will request the municipality board offer sound judgment in this situation for example by delivering the laths....This would mean that we as citizens wouldn't feel observed, and that our family will still be able to sunbath or the like, without taking the different cultural background of the refugee into consideration. (Letter from resident for the public hearing process, $\mathrm{H} \varnothing$ rsholm Municipality, 2015)

At that time, no housing solution had been established in the rather homogenous neighbourhood, and the new spatial diversity is thus represented as felt and sensed abstraction that will have an effect on local life. Several spatial expressions were brought up and discussed, such as the future possibility of sunbathing in the gardens, prospects of rising burglary, fears of decreasing property value and general safety concerns. These expressions define the local by defining how difference can be understood. As in the quote above, we understand that the place of belongingness, the feeling of being at home is, through its symbolics of comfort, security, familiarity and emotional attachment (Hooks, 2009), being acted out in the forums of formal citizenship, and expresses and frames the possible form of differentiated citizenship. This is an example of how planning is connected to the need to belong to certain expressions of value and identity of place. It can be considered a form of "boundary maintenance", which separates 'us' from 'them' (Crowley, 1999), in which feelings of belongings connect with the politics of belonging (Antonsich, 2010). Decision-making is spun by spatial expressions of how a place is felt and lived. Imagination and expressivity thus act as re-territorialisations, which reinstate the local territory and set up certain relations to the refugee.

The expressions are projected onto the possible vision of the other, and a categorisation of the stranger happens accordingly. Instead of a citizen debate that could possibly demystify strangers or enable new encounters, the local debate about refugee housing instead turned into the debate of local identity.

It can be argued that these examples are not only expressions that separate the locals from the others and thus create forms of belonging between certain groups of people. Additionally, the spatial qualities themselves express belonging. The framing of otherness can be seen as an expression written in the spatial and material organisation. As Justin Trudeau notes: "Landscapes be- 
come spatially bounded scenes that visually communicate what belongs and what does not...landscapes are, in part, constructed through a territorialised politics of belonging" (Trudeau, 2006, p. 421). As a visual means of communication landscape thus conveys meanings of inclusion/exclusion. It (re)produces a certain order of things and ideas of cultural unity (Trudeau, 2006).

The former retirement home is the first home in Denmark for the Eritrean community. A physical structure in which they meet local society. In the visual and material sense, it can seem rather paradoxical that they are provided a home in a space originally designed to accommodate a withdrawal from society. When we compare the material expression of the former retirement home to the surrounding residential area, the residents are simply differentiated from the neighbourhood. In the yard of the retirement home bricks have been removed from the pavement as if the structure is in the midst of be- ing dismantled. It is visually evident that the place is in between different temporal events and societal transformations. These elements become part of a visual communication of belonging, which points towards various concepts of time; former place of retirement, temporary housing, paused, partially out of use and to be redeveloped. These temporal conditions are seen in the beginning decay of the structure, as for example in the plants overtaking the building in its unused parts. Many of the surrounding houses have gates to keep people outside. The retirement home is sunken into the land, designed to keep the former residents inside and contributing to expressions about (in)visibility of difference as a form of citizenship practice (see Figures 4 to 6 ). A citizen explains in the local newspaper:

We just moved here, and we have neither experienced anything good or bad with the refugees, and

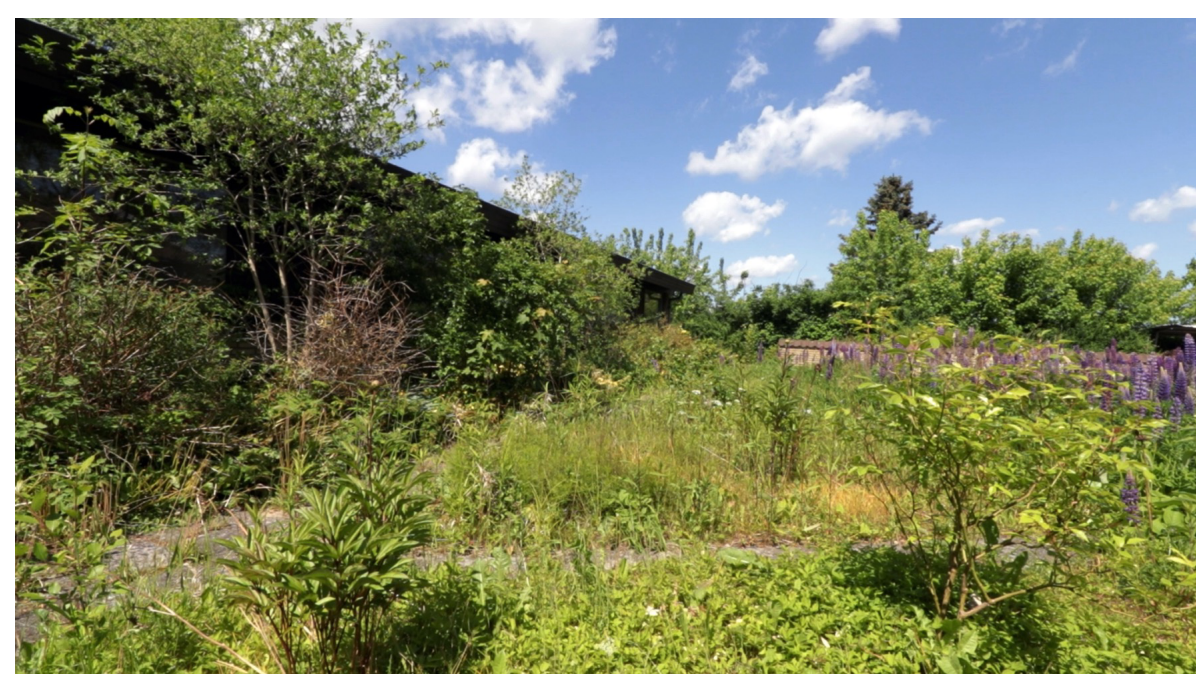

Figure 4. Plants slowly overtaking one of the unused areas belonging to the retirement home. June 2017.

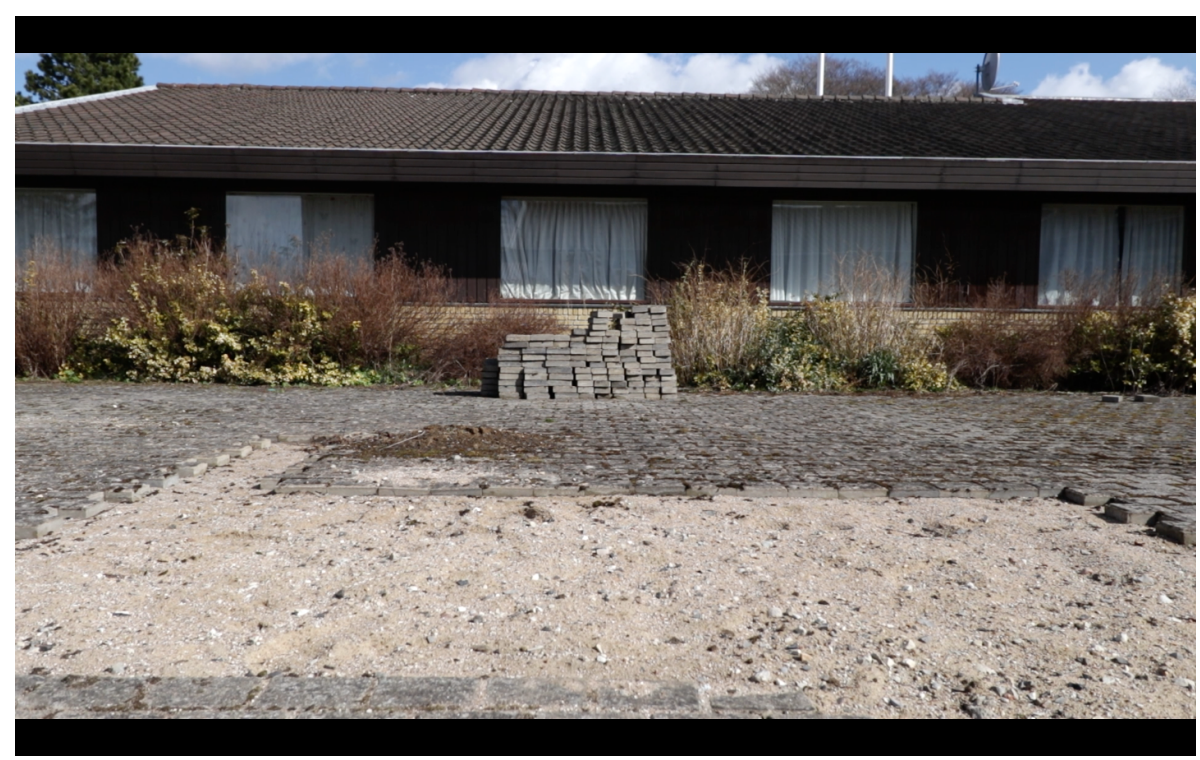

Figure 5. Bricks have been collected and stacked in the yard. March 2017. 


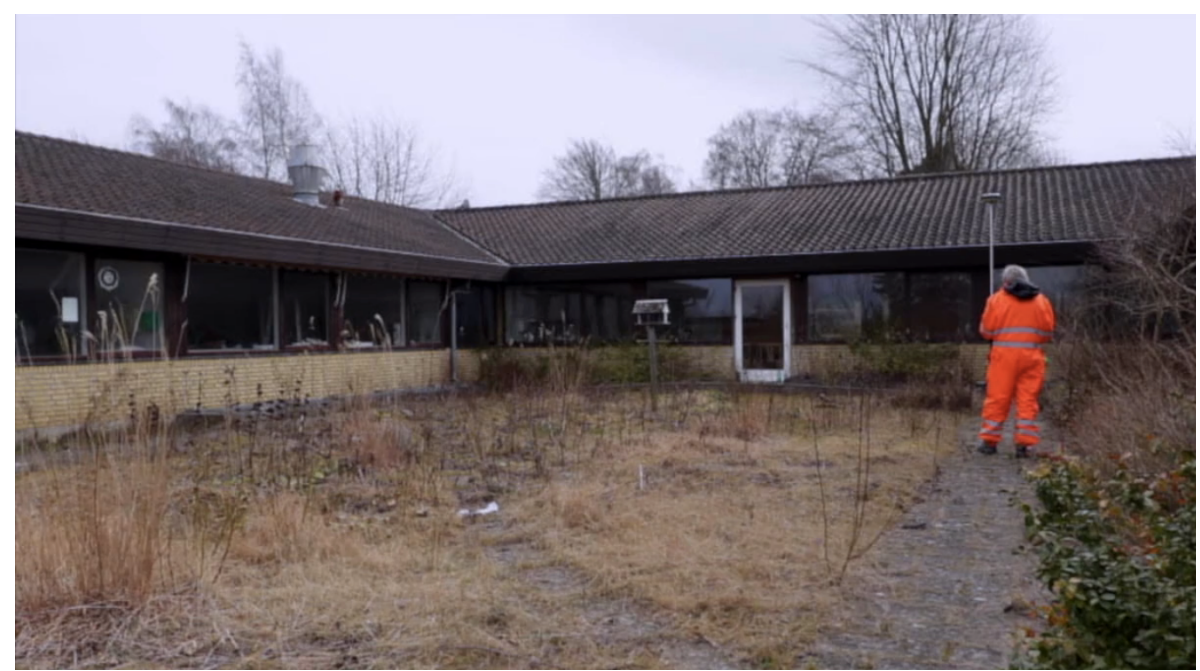

Figure 6. A surveyor measures the plot to prepare for the new construction project. March 2017.

that is after all good in itself. Many people move here to be able to be oneself. Therefore, we don't have any need to interfere too much.

In a neighbourhood of mostly large family-housing units, this quote lets us understand the local spatial conditions of minimal contact with others, in this case, as a search to prolong feelings of tranquillity and peace at home. It is better not to interfere. In fact, not experiencing the other is a quality of the place and a part of the spatial expression that makes people want to live there. Belonging is here connected to a spatial condition of not interfering, which again establishes a non-relation between differences. In this sense, citizenship among the local $\mathrm{H} \varnothing \mathrm{rsholm}$ citizens is practiced as privacy and distance. The urban backdrop, consisting of various houses, becomes the environment onto which this form of citizenship is projected and practiced in everyday life. With this in mind, we see how spatial conditions, and in particular spatial expressions of private space, become a condition for how to act as a citizen. We will shift the perspective from the local neighbourhood framings of otherness and turn towards the perspective of the Eritrean community, which via continuous spatial expressions establishes acts of citizenship between the Eritrean community and society.

\section{Spatio-Temporal Expressions and Everyday Life}

In the following, we discuss the spatial and embodied expressions of becoming citizen. This entails how spatio-temporal expressions of the Eritrean community set up negotiations of belonging and citizenship in relation to society.

As expressed in the public hearing, local planning and the neighbourhood saw the former retirement home as a temporary space, and a space defined in terms of a linearity with a beginning and an end. The timespan of the temporary refugee housing has been publicly known and debated. However, the Eritrean community experiences it as a lived heterogeneous time. When speaking about how long they could live there, the answer was "we don't know" until a few weeks before the relocation to new temporary housing in Hørsholm. Then, the answer changed to "we have to move out soon, but we don't know exactly where or when". Temporality as an experience can be described, through this example, as a series of unknown sequences and unknown functionalities, or shifting sequences without clearly defined beginnings and ends. For the Eritrean community, temporality functions by producing a series of unknowingness. This becomes a condition in the process of becoming citizen and expressing oneself in society, but it also becomes a point of departure for acting out new temporal and spatial expressions. These processes of unknowingness are thus negotiated through various individual and collective acts that instate other spatial expressions of lived experience and practice of time. As Aoileann Ní Mhurchú argues, citizenship is acted out by living through homogenous temporal and spatial boundaries, of past and present, us and them, by fragmenting, overlapping and creating new synergies (Ní Mhurchú, 2014). Citizenship is thus a "form of subjectivity which can also manifest as a cluster of time-space coordinates constantly changing within and across what is normally conceptualised as the absolute space and horizontal time of sovereign political community" (Ní Mhurchú, 2014, p. 216). We saw these forms of subjectivity in various forms of cultural and embodied expressions.

One example is a young resident, who works as a cleaner in the afternoons when the school is emptied of its primary societal function. This action is in itself ambivalent and as he explained, he would "rather be studying in the school, than working there", but the void of the societal function is transformed as a place of acting out and practicing forms of citizenship. By a repeated embodied routine, the place is slowly becoming part of his own expression and contribution to society. He pre- 
pares the place for its primary function and is thus not detached from it. Through the materiality of the place, he connects to the daily rhythms and relates to the social sphere. As he explains "If the students don't hang up the chairs, I won't pass with the mop". His duties are thus performed by the means of relating to the practice of the place, and the time sequence is the time of preparation of the societal function, rather than closing time.

Another example of expressive forms of subjectivity is Sunday mass. The Eritrean Sunday masses took place at various different churches in the capital of Copenhagen. They were a repeating topic of conversation every week, and the community organised events and celebrations collectively. The masses and celebrations took place at various Danish churches, when Danish church communities were not using them. These designated 'odd times' were by the community transformed into spatio-temporal productions embedded with new cultural expressions.
A reframing of the local environment was also found. In February, when the first snow had fallen, the residents gathered outside in the garden to pose, take pictures and share this event online. This act produced a new representation of the place, reimagined as part of a longer travel, a series of experiences and new spatial belongings. Moreover, the community organised new ritual spaces. For instance, they collectively organised a wedding celebration inviting local citizens and Eritrean communities from different parts of Denmark and abroad. The former retirement home was collectively transformed by bodily acts such as dance, song, dining and rituals, and by visual material means through film, photography, decorations and dresses, which enacted the place as a celebration of new beginnings and diverse connectivity (see Figures 7 to 12).

Situations, movements and practices are thus continuously unfolded and reach beyond the former retirement home, escaping local framing conditions and homogenous time. The spatio-temporal conditions trans-

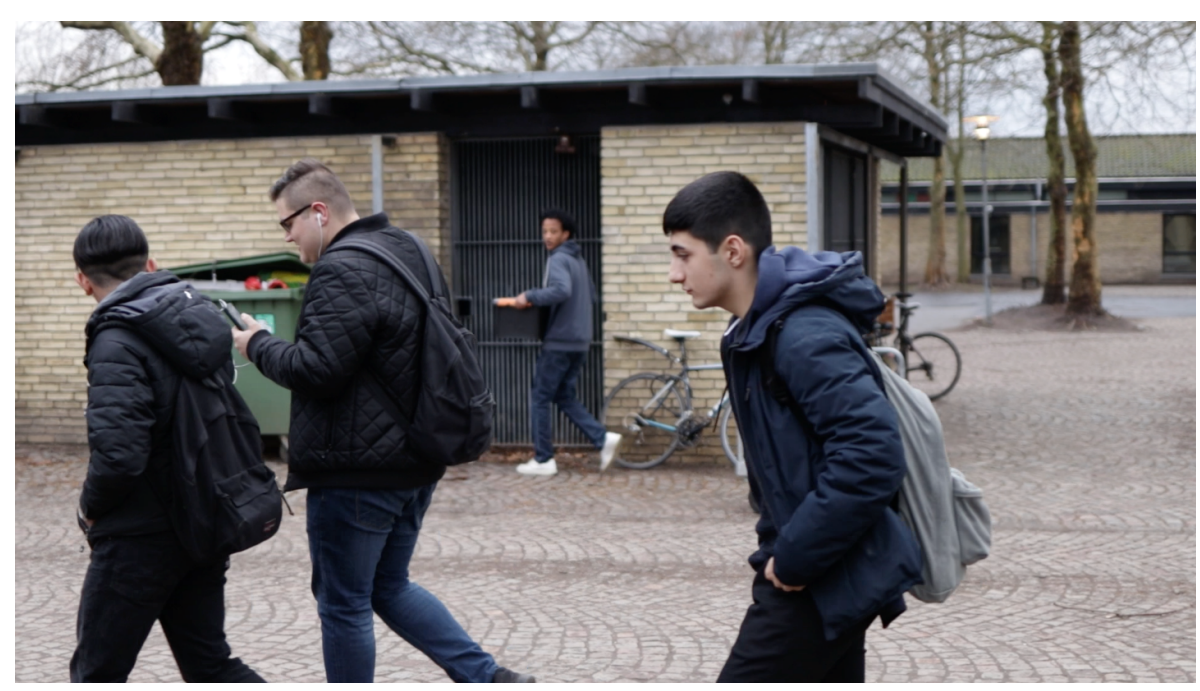

Figure 7. A young resident of the former retirement home works as a cleaner at a nearby school. School lets out as he begins his work. April 2017.

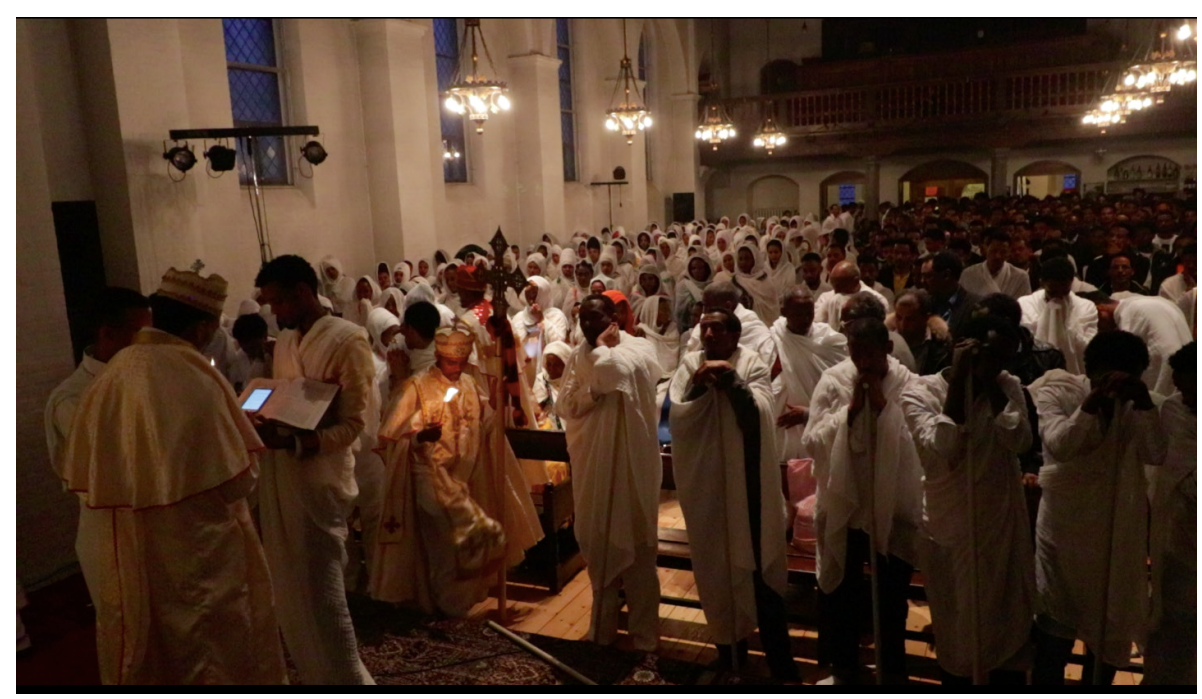

Figure 8. Easter celebration at Blågårds Church in Copenhagen. The priest reads aloud from a smartphone. April 2017. 


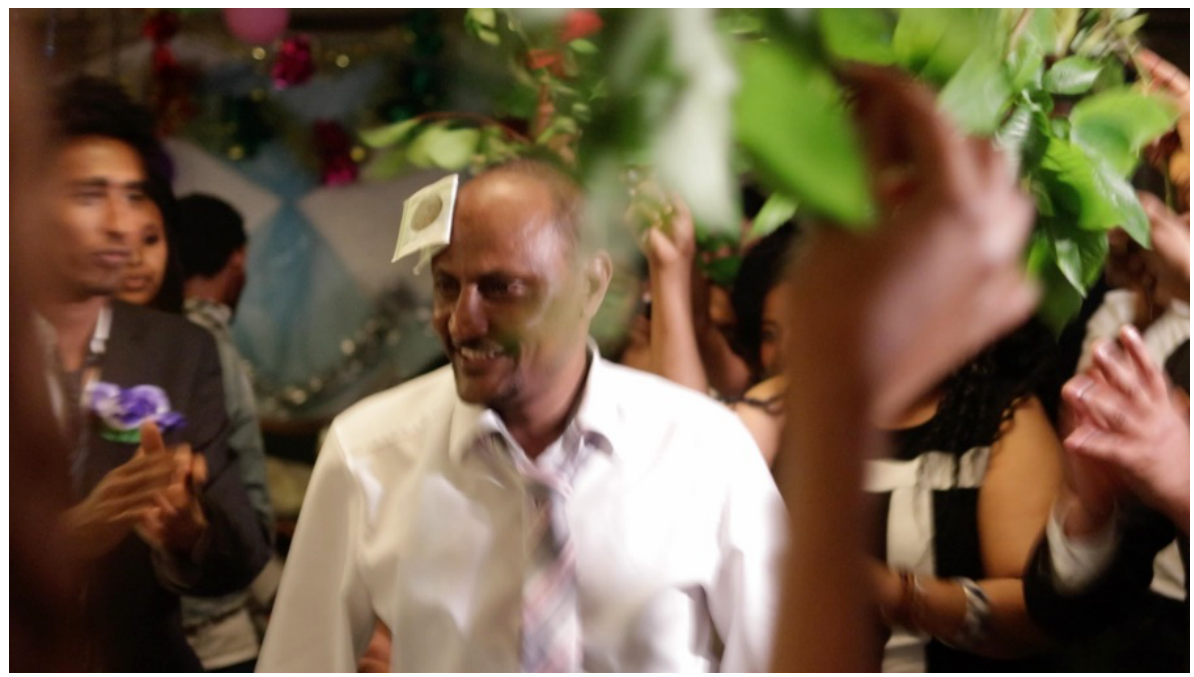

Figure 9. The Eritrean community in Hannebjerg hosted a wedding. During the evening, it was evident how closely connected the various Eritrean communities in Denmark and abroad are, as people came from far away. The evening was full of festivities and the home transformed with long tables, a podium for the married couple, a stage for music, flags, balloons and flowers. Rituals were performed throughout the evening. One of the final performances was the dance of the groom, where the surrounding participants attached 100 and 200 DKK bills to his forehead. May 2017.

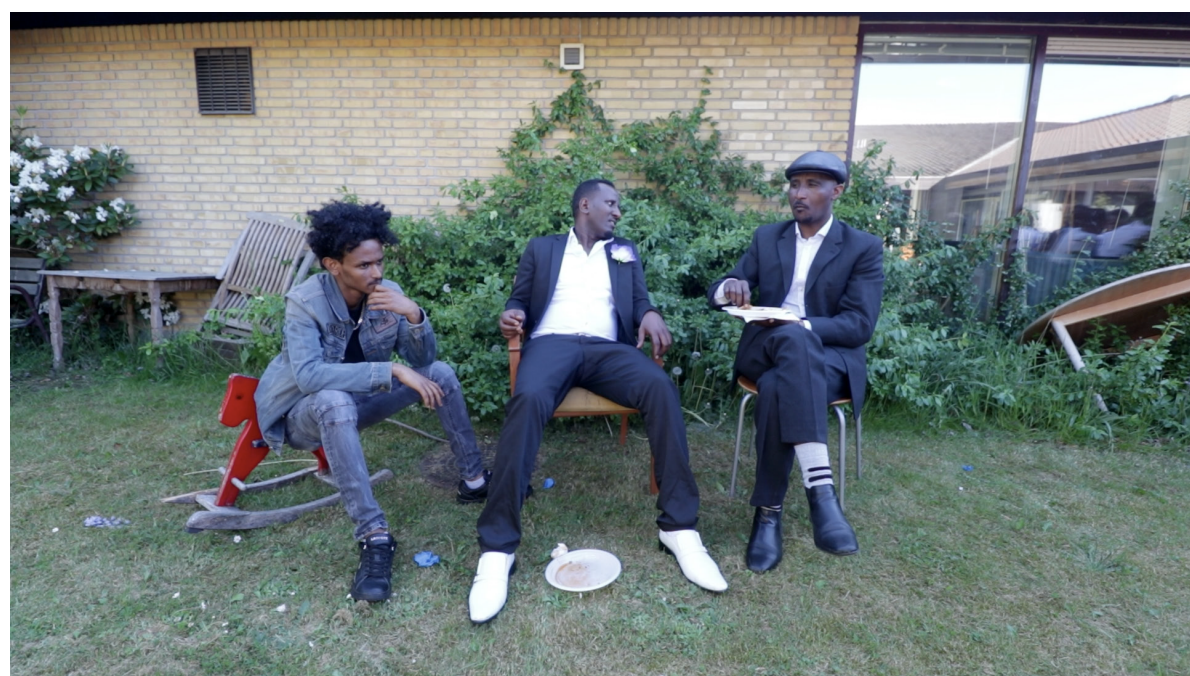

Figure 10. Wedding. Guests sitting in the garden. May 2017.

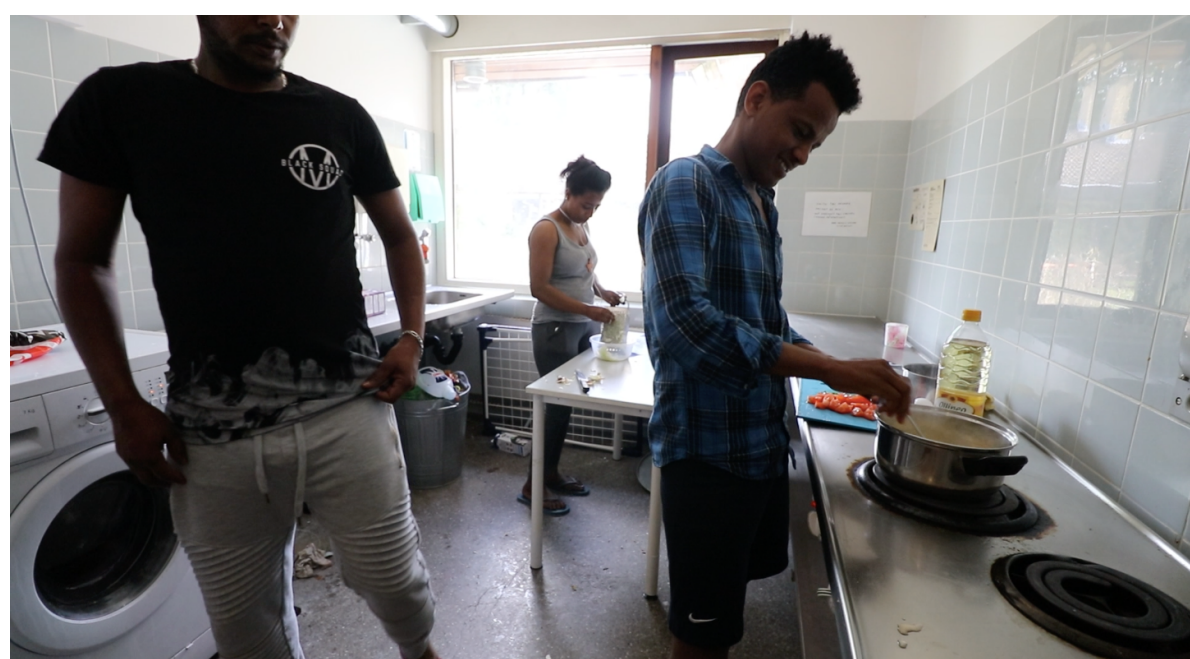

Figure 11. There would often be power outages in the kitchen, which disabled the stove. The residents would use the stove in the laundry room when the power outages occurred. April 2017. 


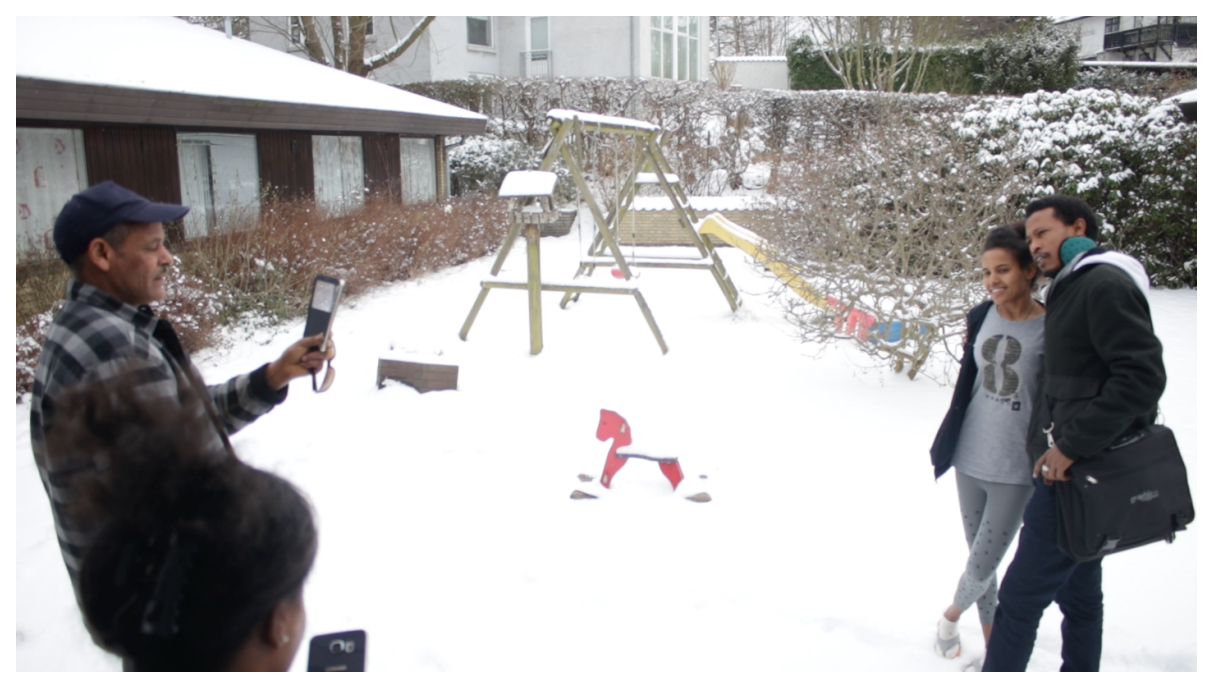

Figure 12. It was the first Danish winter for many of the residents of Hannebjerg. In early February, the first snow came, and the residents went outside to take pictures in the white scenery to share with their friends and families in Eritrea. February 2017.

form into acts that reimagine place and function. Beginnings and synergies are acted out as way of relating to society by assembling diverse temporal and spatial expressions.

In this sense, these acts can be seen as active transformations of the landscape, which create new assemblages of belonging cutting across boundaries, thus disintegrating and reformulating spatial and temporal conditions. What is essential is that spatio-temporal expressions, which in a sedentary sense are connected to pause, out-of-use, odd time and temporality, are continuously re-enacted and transformed by the Eritrean community as spaces of cultural belonging and production. This signifies citizenship as a creative act that finds places, utilises the unused and establishes possibilities in the margins and pockets of the society.

This example iterates the discussion about belonging in the intimate spheres of the home as a place of broader social negotiations, claiming belonging and justifying it (Antonsich, 2010). Just as the previously observed local framing of mobile peoples can be seen through the perspective of belonging to an expression of place, the Eritrean community also acts through home decorations that express connectedness and cultural bricolage rather than disconnectedness and material decay. The homemaking thus becomes a way of transforming material conditions into a connectivity to society. Each resident has his own small single room. A common way of furnishing the rooms is to have several sofas. This is a way of opening up the privacy to social flow and hospitality. In one room a post-it note on the wall states: "Read the newspaper out loud, find someone to practice Danish (native), just speak". It engages citizenship as a means of social relation, practice and exchange. Religious Eritrean posters hanging next to Danish flags and football medals as well as decorations covering the hoist on the ceiling are simple acts of combining, erasing and transforming the material conditions into multiple connotations of mixing culture, identity and place as ways to actively engage and transform society (see Figures 13 to 17 ).

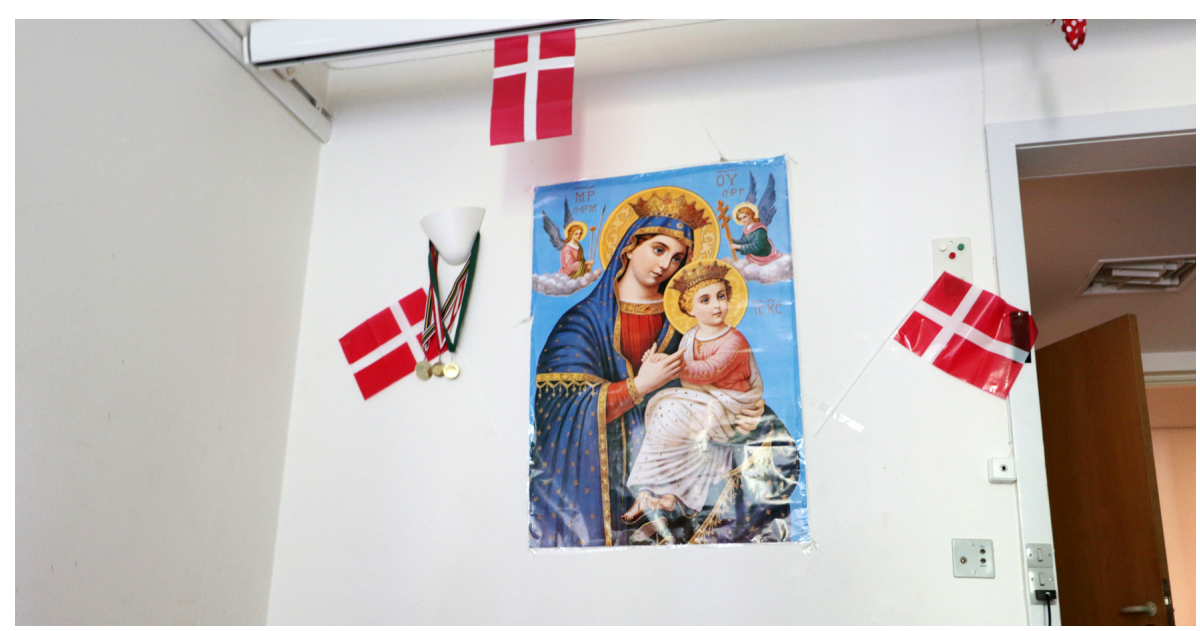

Figure 13. Poster of the Virgin Mary, Danish flags and football medals. April 2017. 


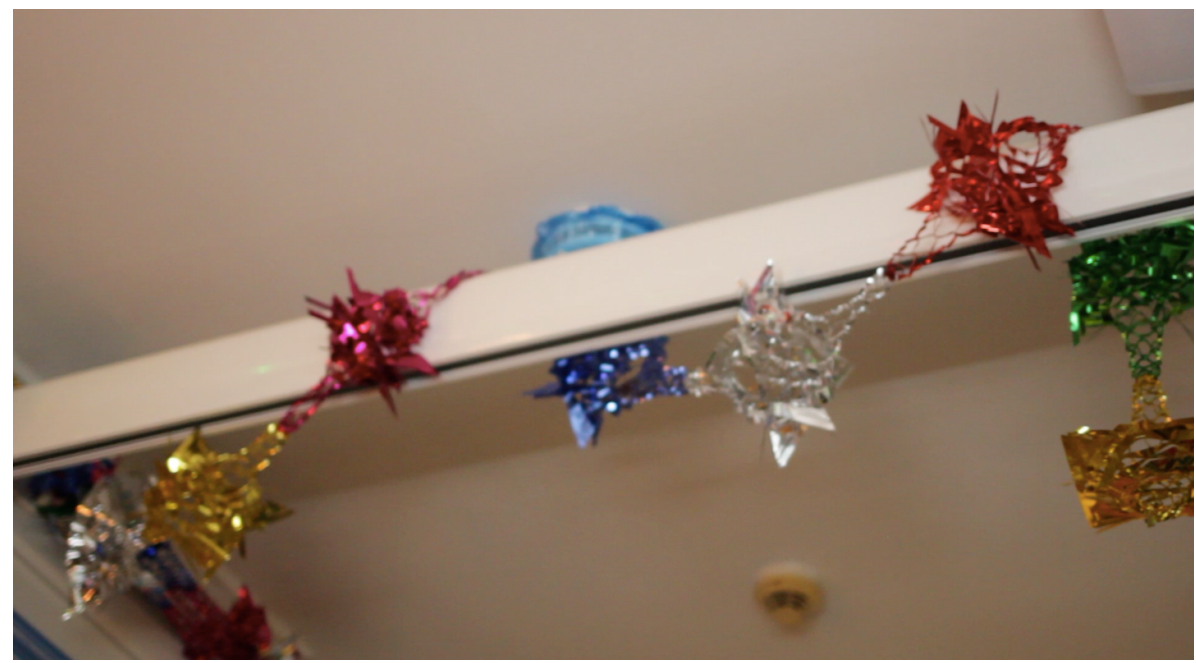

Figure 14. Decorations covering the hoist on the ceiling. April 2017.

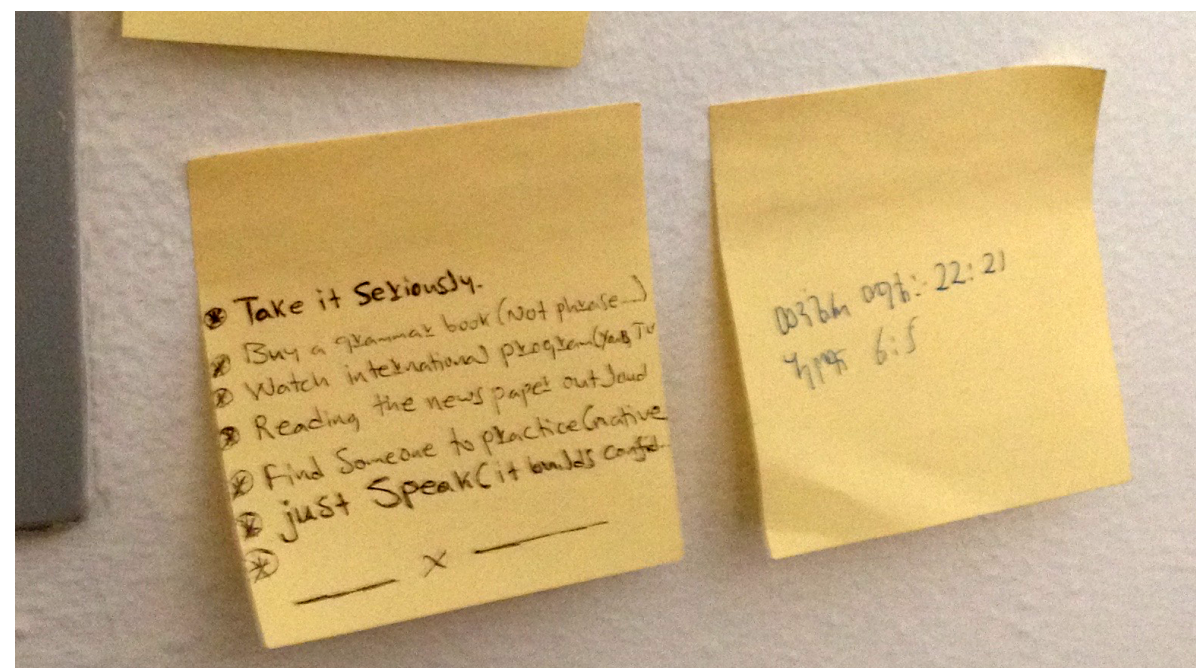

Figure 15. Post-it notes in Yohannes' room. Some of the text reads: "Which International programs?" "Read the newspaper out loud." "Find someone to practice Danish (Native)" "Just speak." April 2017.

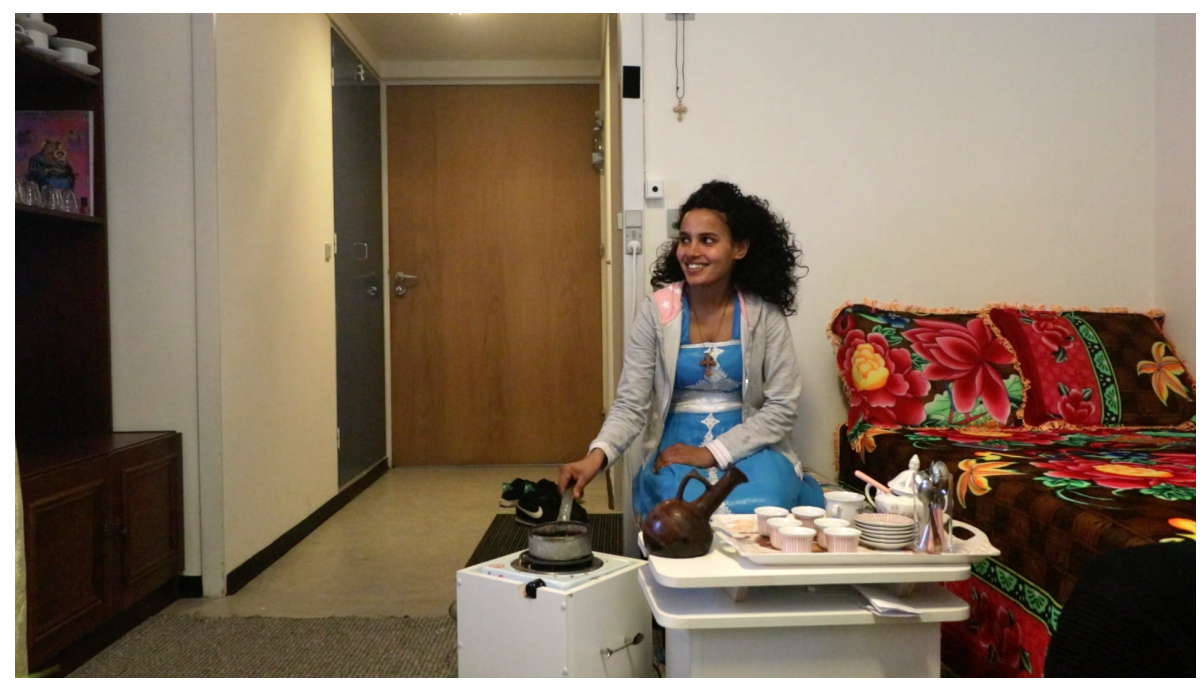

Figure 16. Kistane in her room, preparing Eritrean coffee on a mobile stove. April 2017. 


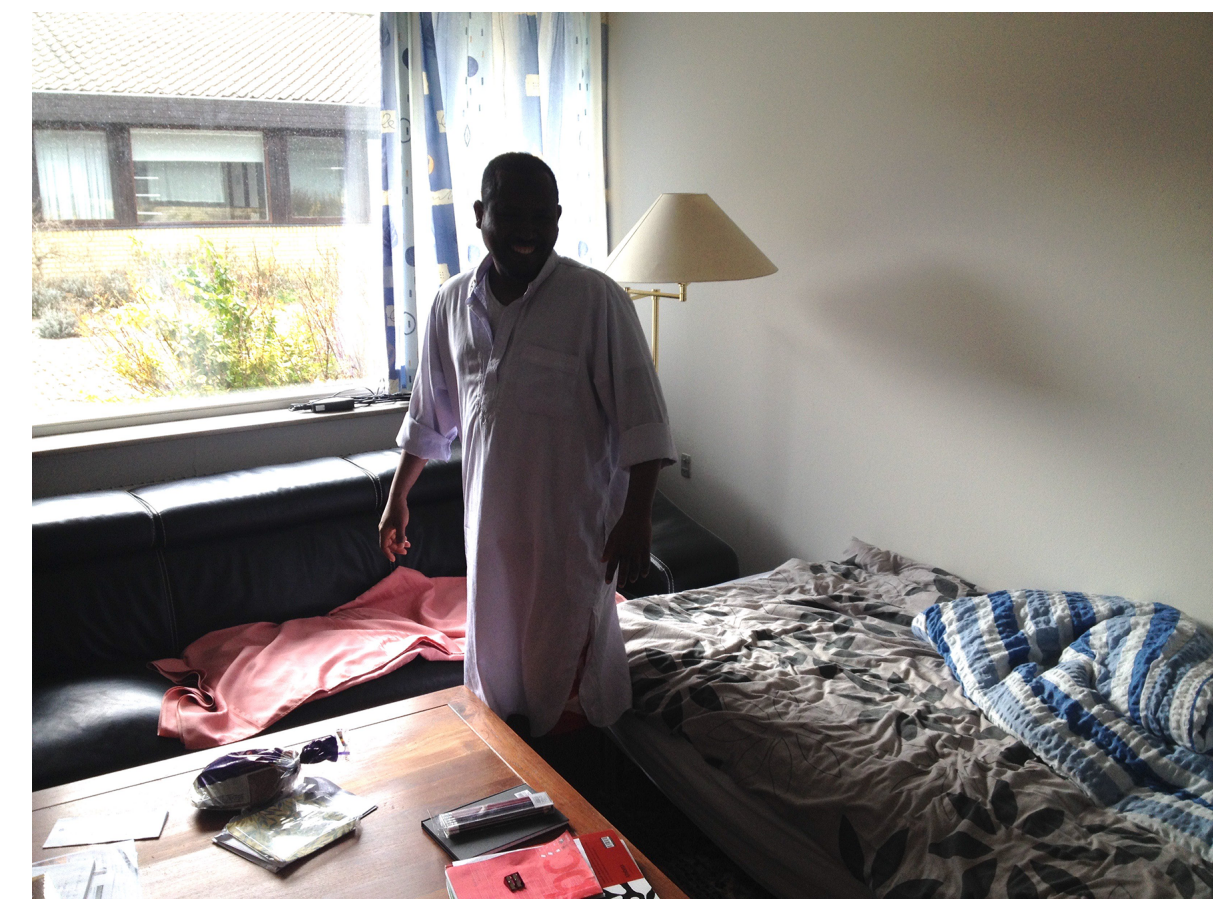

Figure 17. Saleh in his room. Even though the rooms are very small, most were furnished with a bed, a couch and chairs. The rooms are thus accommodated to host many guests. May 2016.

\section{Becoming, Media and Youth}

In this section, we analyse how becoming citizen, approached through acts of media culture, desire and youth, transforms the conditions and possibilities of citizenship as it is connected to becoming global (see Figures 18 to 24).

As mentioned previously, we understand mobile peoples as figures of bricolage that practice cultural belonging without anchorage in national culture, but rather bringing together various expressions from global culture. When we look to the Eritrean community and their expressions of belonging, they are formed between places, timespans, cultures and identities. Becoming cit- izen is neither a one-way process nor a movement from one place to another. Rather, it is related to the process of stretching in-between, continuously connecting to and disconnecting from former and new environments, cultures, gestures, images and expressions. In this context, we consider becoming citizen as a performative act that goes beyond national subjectivity and sedentary citizenship as it enables a more fluent global belonging. In this process of becoming citizen, we thus identify a capacity to creatively transform the meaning and function of citizenship (Isin, 2017). An example could be our conversation with a Syrian woman, Aisha, who previously lived in the former retirement home, as she explained her desire for Danish citizenship: "In the future, if we get the

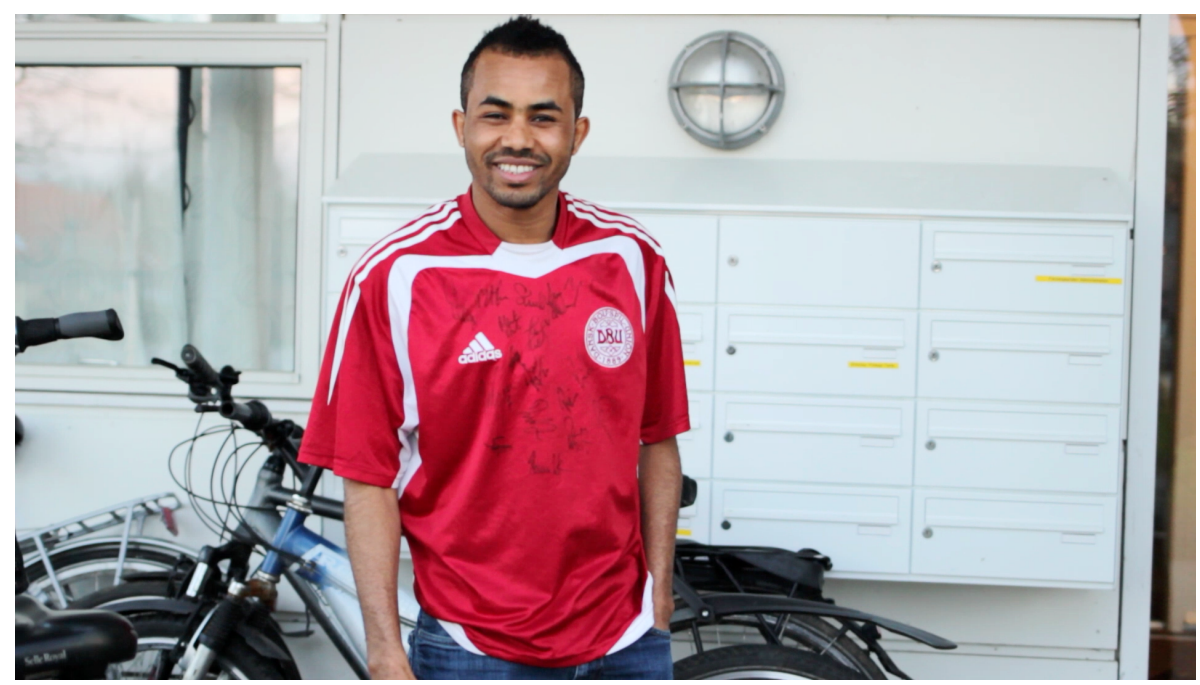

Figure 18. Ermiras wearing a t-shirt of the Danish national football jersey signed by all the players. May 2017. 


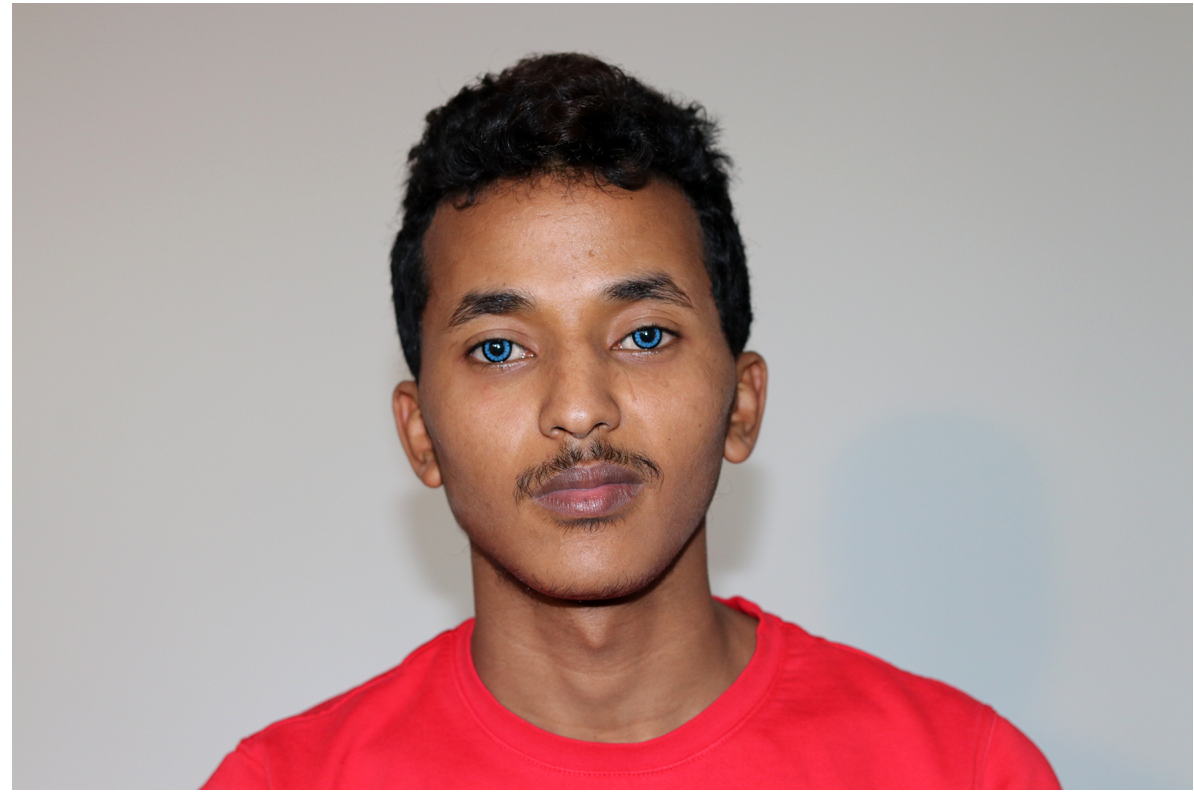

Figure 19. Shirak wearing his new blue contact lenses. March 2017.

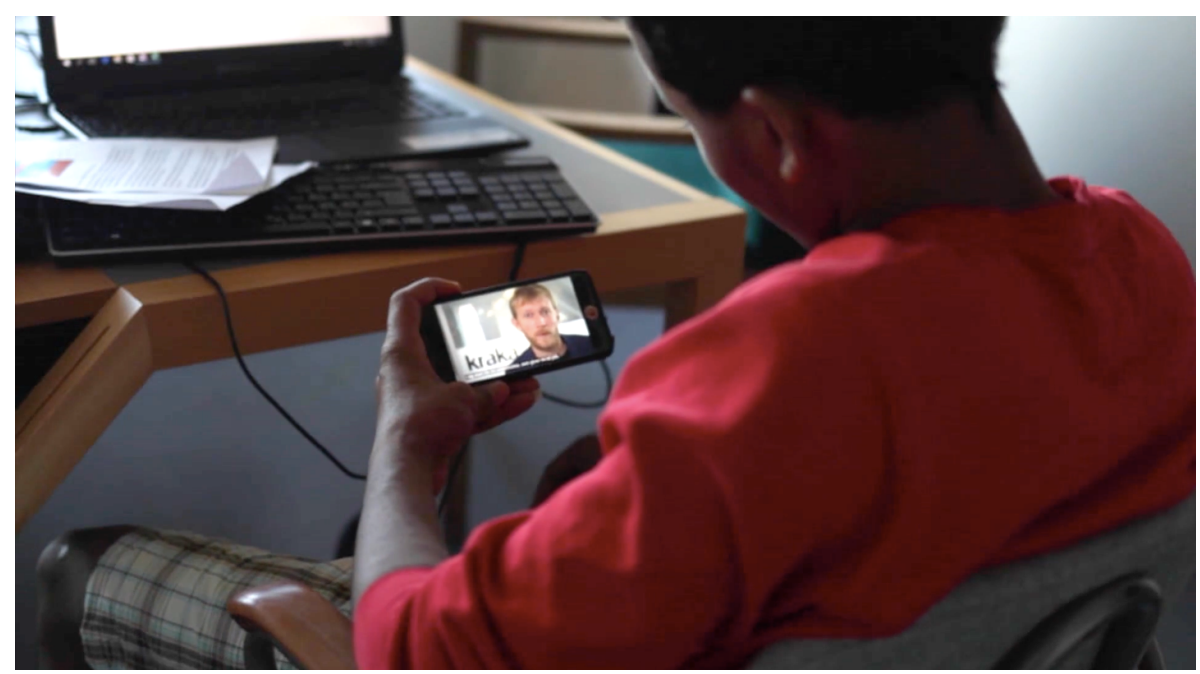

Figure 20. Shirak watches videos about integration, broadcast by the Danish national TV station, DR. In the videos, politicians and citizens explain their opinions on what they think is good integration. March 2017.

Danish citizenship, we can visit Palestine again. Maybe we will die, maybe we will return to Syria, we don't know what will happen in the future".

In this quote, Aisha characterizes citizenship not as something tantamount to settling down, but rather as a gateway to enhance her mobility and engage and confront new potential belongings. Following Antonsich, we could argue that Aisha is expressing a non-belonging, which is usually "associated with a desire of longing and a yearning for the 'lost' place, which might feed a 'myth of return'" (Antonsich, 2010, p. 17). Furthermore, this desire of longing or yearning for a lost place might not just be seen as a territorial lack or a loss but could also be seen as a productive desire and a re-territorialisation. According to Isin, we can understand it as a production of subjectivity, and a rights-claim, where "people enact citizenship by exercising, claiming and performing rights and duties" (Isin, 2017, p. 501). Aisha shares a desire of citizenship, which is not connected to the lack of feeling Danish, Palestinian or Syrian. It is rather the desire of continuous de-territorialisation and re-territorialisation; a stretching life in-between the territorialised spaces of various nation states.

In a formal sense, becoming a Danish citizen can be perceived as something static and safe, leading towards settling down. In this case, however, it is tantamount with continuously exercising new right claims to move and belong in between what Ní Mhurchú calls the "categories of migration and citizenship" (Ní Mhurchú, 2016, p. 159). In other words, Aisha can be seen as performing citizenship by not only exercising her right as a citizen, but also "claiming rights and duties yet to come as 


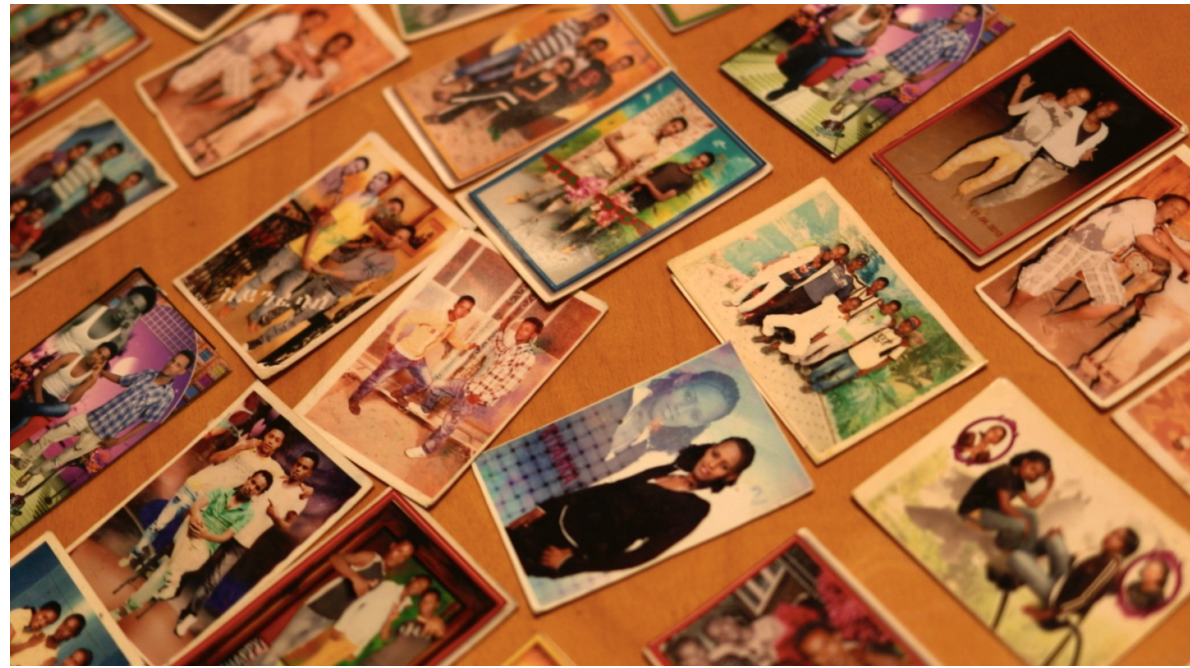

Figure 21. Mhretab's pictures from Eritrea and Sudan of his family, friends and girlfriends. March 2017.

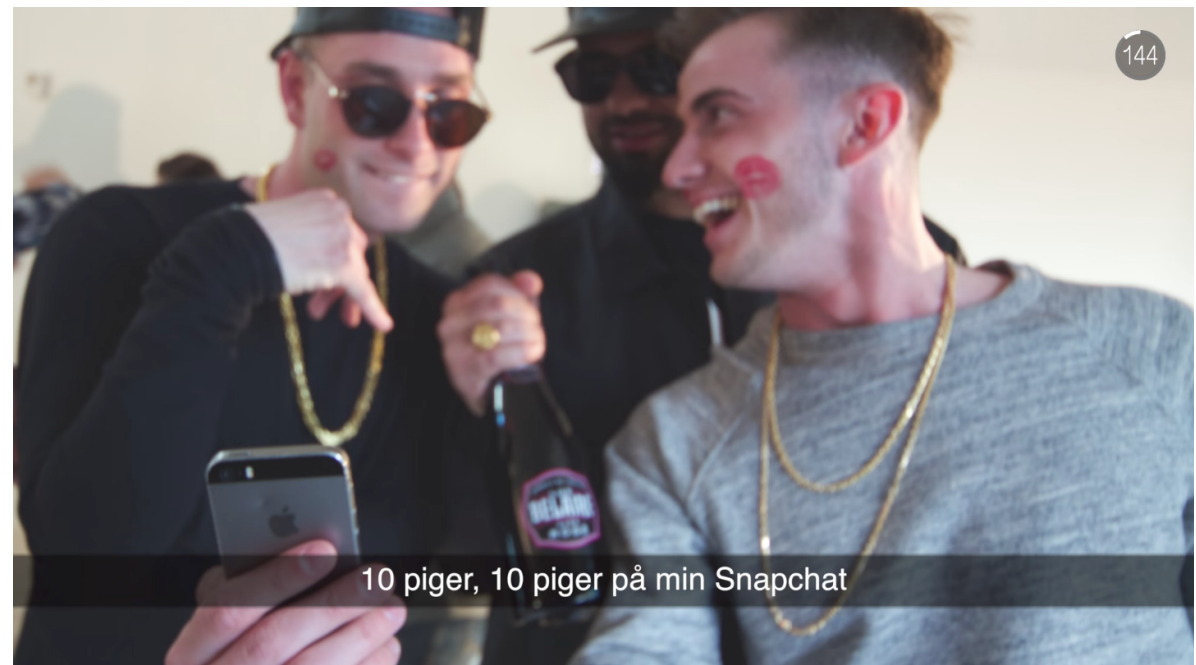

Figure 22. Screenshot from the music video "Ladies in stock", with the text: "Ten girls, ten girls on my Snapchat," in Danish. Released in 2016 on Jimilian's third studio album Me and Myself (Jamilian, 2016). May 2017.

a result of social struggles" - which Isin defines as "the right to claim rights" (Isin, 2017, p. 506). Becoming citizen and performing citizenship is in this sense not movement towards a singular and original nationality, rather it is a potential to becoming Syrian or Palestinian. In a similar sense, Danish citizenship is both the connection to and disconnection from a Danish identity, belonging and territory.

This ambiguity of becoming is an essential point for understanding its performative dimensions and possibilities. Citizenship is not enclosed in itself but emerges as a relation to other becomings. For instance, for the residents who recently finished educations, the idea of becoming citizen is connected to finding a job in Denmark. For others, such as those who just got married or had a child, becoming citizen would be connected to having a family reunification. One example is Gareth, who argues: "If I am not able to get my wife and child here, then there is no reason for me to stay. How should I make a life here without my family?"
Another heterogeneous act of becoming citizen is performed by the young men between seventeen and twenty-four. They have all spent years of their adolescence on the move; escaping from the regime in Eritrea, living in camps in Ethiopia, Sudan and Libya, crossing the Mediterranean Sea and travelling through Europe before arriving to Danish asylum camps. Under these circumstances, they experienced a turbulent childhood, in which they have been connected to and disconnected from various places, people, cultures and languages. This process entails complexities in terms of belonging. As Ní Mhurchú argues, the intergenerational migrant youth can be viewed as negotiating home and belonging in various affiliations towards often-contradictory cultural, linguistic and geographic identifications, which disrupts the opposition between roots and routes, or movement and attachment (Ní Mhurchú, 2016). On their journey from the different camps and homes in Northern Africa and later in Europe, they have been exposed to several languages, cultures, people and places. A condition of their 


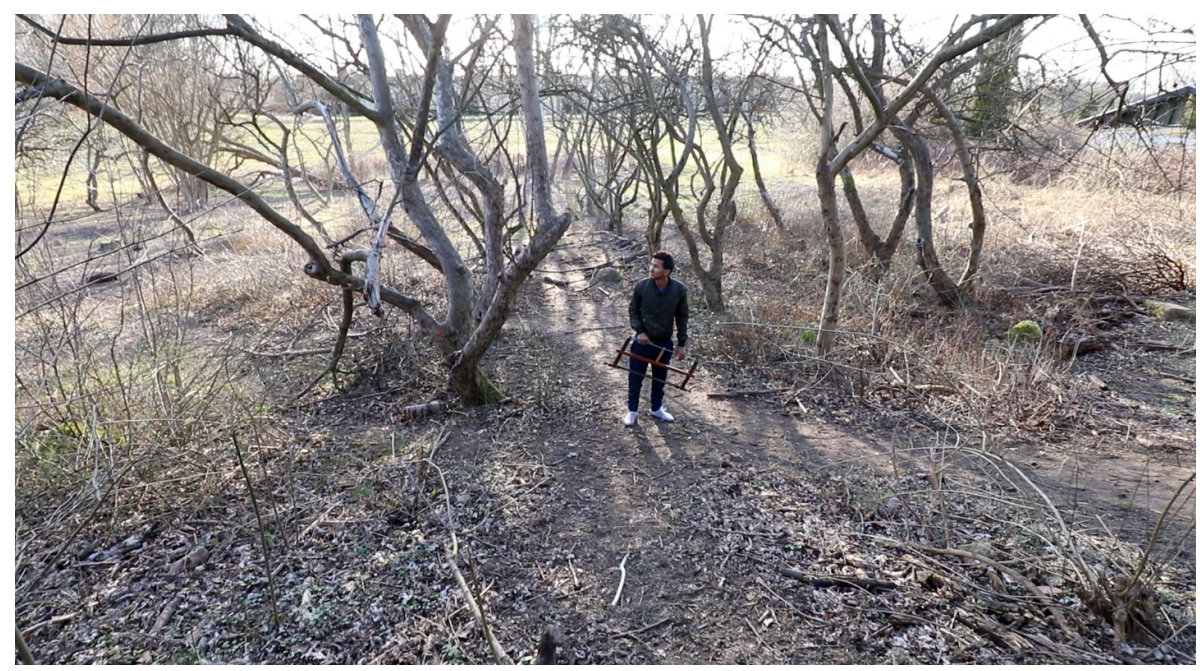

Figure 23. Shirak is making a scene for the film where he search for a branch to create a slingshot. When he lived in Asmara, he used to hunt pigeons with his homemade slingshot. He would sneak up close to them, and hurl a stone at their wings and thus catch them. He would bring them back and sell them at the market. In this way, he would earn money to spend in the evening at an internet cafe with his friends. March 2017.

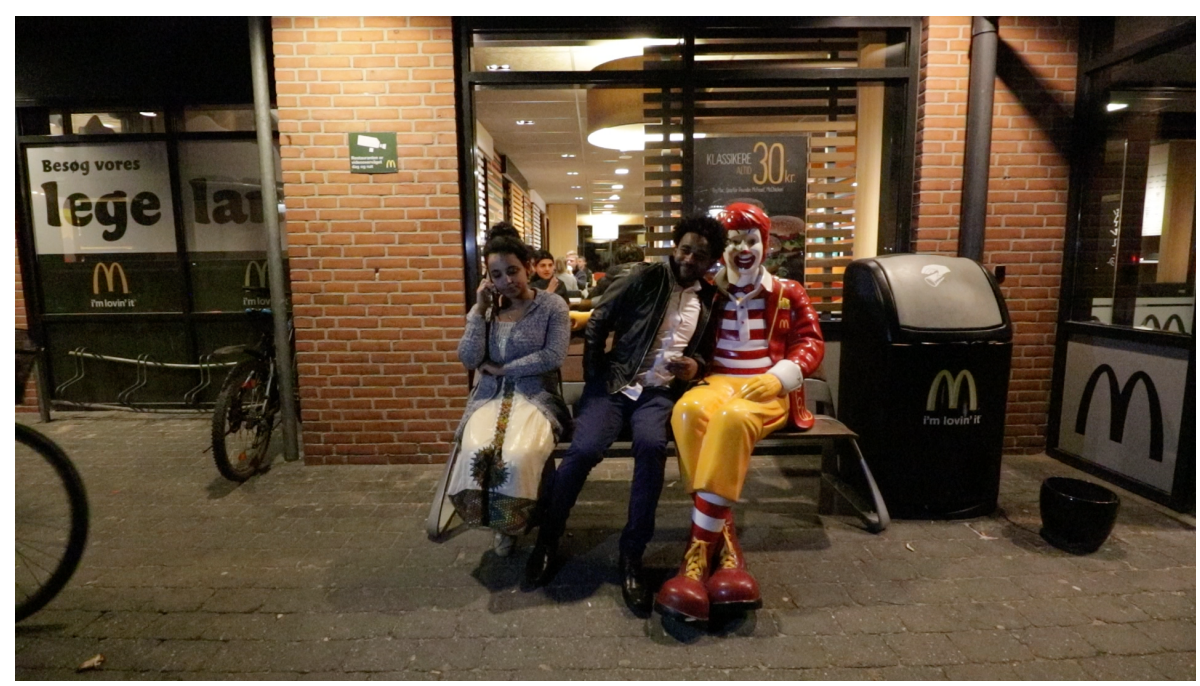

Figure 24. After celebrating Good Friday, the whole community went to get a snack at McDonald's. John poses with Ronald McDonald, while his sister Habtom is on the phone with their family. April 2017.

time on the move has been that they have been curbing with their youth. What could be understood as a repressed childhood, unfolds here instead as the desire and production of the early manhood. Thus, the desire to become citizen is in this sense connected to becoming young. In this case, becoming young is not to be understood in a linear timeline before manhood, rather it is the process of realising potentialities in a mobile life. The boys of the community do not escape or lack their childhood, but they desire it through 'germinal influxes of intensity' (Deleuze \& Guattari, 1987, p. 164). In this context, we identify a vitalist production of youth rather than the lack of it (Ljungstrøm, 2000).

Another example of how becoming citizen is connected to the vitalism of becoming young is seen in the residents' connectivity to Danish popular culture.
There are a lot of ladies here, but there is always room for more. You know exactly where I am, I swear I got ladies in stock. (Jamilian, 2016)

The younger residents listen to Danish pop music. A popular artist is Jimilian, a twenty two-year-old AlbanianDanish pop singer. One of his hits, Ladies in Stock (Damer på lager), is often played in the residence, as a popular refrain among the young residents. The music video is produced as a Snapchat story, collected from Jimilian's fans, and the lyrics of the song are presented as Snapchat text. The lyrics are easily accessible and carry a strong desire for fame, intoxication, wealth and sensual drive.

The Snapchat concept is relatable and effective because it forms a nomadic bricolage of vital moments that smoothens territories and portray a fluent and global 
community as an elite of mobility. In this way, we can see that the young residents approach citizenship by connecting to a desire for youth and popular culture, but also as a connection to a virtual and fluent community (see Figure 26).

Following Caitriona Ní Laoire, Carpena-Mendez, Tyrrell and White (2011) in their study of African and Latin American youth migrants living in Ireland, we can argue that music is likewise connected to the way the youth become citizens through enactments of a global belonging. As Ní Mhurchú argues: "What became important for such youth was developing belonging via globalised culture, including through music (such as rap) and languages...among like-minded peers in response to experiences of marginalisation and isolation" (Ní Mhurchú, 2016, p. 160).

This adaption of popular music differentiates from a general application of citizenship and Danish culture because it is accessible virtually, as well as faster to understand, consume and distribute. The video becomes a culturally performed expression for the community both to re-territorialise Danish culture and to re-distribute it beyond its borders. It illustrates that connecting to Denmark is enacted with awareness of its possible connections to a global community.

What might not be accessible social citizenship on a spatial, local or national level could connect to a virtual mobility in the global community. The mobile peoples become citizen through expressions practiced beyond the institutional system of the nation state and local society. Thus, the conditions of becoming citizen are reformulated according to the many-sided movement of the Eritrean community as an essential mobile people. This allows new means of becoming citizen, for example through virtual platforms, in which becoming citizen is a connection to an imaginary and fictive community beyond the local and national expression. As a further comment and a distribution to the ongoing writings on post-migration, performative citizenship and becoming citizen, we can add that citizenship is not only performed across social groups and polities (Isin, 2017). It is likewise a performative bricolage with an inherent awareness and a desire towards the global community. It holds the potential to transform, de-territorialise and re-territorialise citizenship as defined by the national state.

\section{Conclusion}

Our article has contributed empirical examples of what Isin frames as performative citizenship-with a special interest in the embodied, spatial and socio-cultural expressions. In this article, we have examined the conditions and expressions of how refugees in Denmark become citizens. We have argued that becoming citizen is a condition that appears through spatial and expressive negotiations between the local society and the Eritrean community. We have described how the refugee is framed through national media as a figure of escape, and we have argued how this discourse is repeated and localised in the city of Hørsholm, shaping spatial conditions of citizenship. The spatial conditions of how a place is felt and lived reinstate the logic and values in local territory. For instance, we have seen how the urban backdrop is an environment where sedentary forms of citizenship are projected and practiced. Furthermore, we have explored everyday spatio-temporal expressions as a form of transforming citizenship by performative acts. Mobile peoples can be seen as becoming citizens throughout manifold expressions and bricolages. We have pointed out how the local spatio-temporal conditions are transformed into acts that reimagine places and functions; where beginnings and synergies are acted out by assembling diverse temporal and spatial expressions. Likewise, homemaking and every day rituals can be seen as acts that erase, combine and transform belonging; they are, as well, acts expressing connectedness and cultural bricolage. Becoming citizen is thus not a one-way process or movement from one place to another. Rather it relates to the process of stretching in-between, continuously connecting to and disconnecting from former and new environments, cultures, gestures, images and expressions. With this is mind, citizenship can be seen as a performative act that goes beyond national subjectivity and sedentary citizenship. Performative citizenship allows multiple fluent and global belongings. As unfolded in the last part of the analysis, this is often practiced with an awareness and a desire towards the global community, with the potential to transform and de-territorialise the nation state, its culture and territorial boundaries.

\section{Conflict of Interests}

The authors declare no conflict of interests.

\section{References}

Antonsich, M. (2010). Searching for belonging: An analytical framework. Geography Compass, 4(6), 644-659.

Appadurai, A. (1997). Modernity at large: Cultural dimensions of globalization. Minneapolis, MN: University of Minnesota Press.

Appadurai, A. (2006). Fear of small numbers: An essay on the geography of anger. Durham, NC: Duke University Press.

Appadurai, A., \& Holston, J. (1996). Cities and citizenship. Public Culture, 8(2), 187-204.

Bell, D. (2010). Fail again-Fail better: Nomadic utopianism in Deleuze \& Guattari and Yevgeny Zamyatin. Political Perspectives, 4(1), 6-38.

Bishop, C. (2012). Artificial Hells: Participatory art and the politics of spectatorship. London: Verso.

Bromley, R. (2017). A bricolage of identifications: Storying postmigrant belonging. Journal of Aesthetics \& Culture, 9(2), 36-44.

Cresswell, T. (2006). On the move: Mobility in the modern Western world. London: Routledge. 
Crowley, J. (1999). The politics of belonging: Some theoretical considerations. In A. Geddes \& A. Favell (Eds.), The politics of belonging: Migrants and minorities in contemporary Europe (pp. 15-41). Aldershot: Ashgate.

Deleuze, G., \& Guattari, F. (1987). A thousand plateaus. London: Bloomsbury Academic.

Diken, B., \& Laustsen, C. B. (2003). Den evige nomadeom dansk indvandrerpolitik set $i$ lyset af globalisering, multikulturalisme og ret (Working Paper). Lancaster: Department of Sociology, Lancaster University. Retrieved from www.lancaster.ac.uk/ fass/resources/sociology-online-papers/papers/diken -laustsen-evige-nomade.pdf

Guattari, F. (2000). The three ecologies. London: The Athlone Press.

Hacking, I. (2002). Historical ontology. Cambridge, MA: Harvard University Press.

Hamann, U., \& Yurdakul, G. (2018). The Transformative forces of migration: Refugees and the reconfiguration of migration societies. Social Inclusion, 6(1), 110-114.

Holston, J. (2011). Contesting privilege with right: The transformation of differentiated citizenship in Brazil. Citizenship Studies, 15(3/4), 335-352.

Hooks, B. (2009). Belonging: A culture of place. New York, NY: Routledge.

Hørsholm Lokalavis. (2015, May 21). Flygtninge: 'Hannebjerg skal give os et tiltrængt pusterum'. Hoersholm Lokalavis. Retrieved from hoersholm.lokalavisen.dk/ nyheder/2015-05-21/Flygtninge-'Hannebjerg-skalgive-os-et-tiltrængt-pusterum'-1247009.html

Hørsholm Lokalavis. (2016, August 31). Naboer til flygtninge: 'Det er som om de skjuler sig'. Hoersholm Lokalavis. Retrieved from hoersholm.lokalavisen. dk/nyheder/2016-08-31/Naboer-til-flygtninge-'Deter-som-om-de-skjuler-sig'-1117598.html

Isin, E. (2018). Mobile peoples: Transversal configurations. Social Inclusion, 6(1), 115-123.

Isin, E. F. (2012). Citizens without nations. Environment and Planning D: Society and Space, 30(1), 450-467.

Isin, E. F. (2017). Performative citizenship. In A. Shachar, R. Bauböck, I. Bloemraad, \& M. Vink (Eds.), The Oxford handbook of citizenship (pp. 500-523). Oxford: Oxford University Press.

Isin, E. F., \& Turner, B. S. (2002). Handbook of citizenship studies. Thousand Oaks, CA: SAGE Publications.

Jamilian. (2016). On Mig og Mig Selv (Music album). Denmark.

\section{About the Authors}

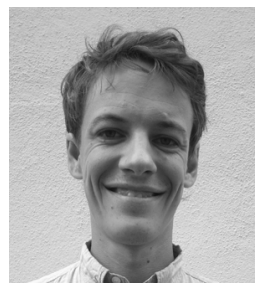

Peter Kærgaard Andersen (1988) is graduated in Urbanism and Performance Design at Roskilde University, 2017, and is part of the art and research duo Jamboy (2013). Jamboy is working with interdisciplinary approaches, creating projects that explore aesthetic and social sides of globalization, ecology, urbanism, and new medias. Often pursuing socially grounded processes of art and research intervention they search to establish new reflection and thought on contemporary phenomena by applying a diverse, humorous and poetic imagery.
Kandylis, G. (2017). Urban scenes of citizenship: Inventing the possibility of immigrants' citizenship in Athens. Citizenship Studies, 21(4), 468-482.

Kester, G. (2011). The one and the many. Durham, NC: Duke University Press.

Lash, S., \& Urry, J. (1994). Economies of signs and space. London: Sage.

Lelandais, E. G. (2013). Citizenship, minorities and the struggle for a right to the city in Istanbul. Citizenship Studies, 17(6/7), 817-836.

Ljungstrøm, C. A. (2000). Radikalt demokrati og nomadisk ret: Spinoza, Negri og Deleuze. Slagmark, 30, 73-103.

Ní Laoire, C., Carpena-Mendez, F., Tyrrell, N., \& White, A. (2011). Childhood and migration in Europe. Farnham: Ashgate.

Ní Mhurchú, A. (2014). Traces rather than spaces of citizenship: Retheorising the politics of citizenship. In A. Ní Mhurchú (Ed.), Ambiguous citizenship in an age of global migration (pp. 190-219). Edinburgh University Press.

Ní Mhurchú, A. (2016). Unfamiliar acts of citizenship: Enacting citizenship in vernacular music and language from the space of marginalised intergenerational migration. Citizenship Studies, 20(2), 156-172.

Papastergiadis, N. (2000). The turbulence of migration: Globalization, deterritorialization and hybridity. Malden: Polity Press.

Pink, S. (2009). Doing sensory ethnography. London: SAGE Publications.

Pink, S. (2011). Doing visual ethnography. London: SAGE Publications.

Reestorff, C. M. (2017). Culture war: Affective cultural politics, tepid nationalism and art activism. Bristol: Intellect.

Sheller, M., \& Urry, J. (2006). The new mobilities paradigm. Environment and Planning A: Economy and Space, 38(2), 207-226.

Stage, C. (2011). Tegnkrisen: Som mediebegivenhed og danskhedskamp. Aarhus: Aarhus University Press.

Tomlinson, J. (1999). Globalization and culture. Cambridge: Polity Press.

Trudeau, D. (2006). Politics of belonging in the construction of landscapes: Placemaking, boundary-drawing and exclusion. Cultural Geographies, 13(3), 421-443.

Yiftachel, O. (2006). Ethnocracy: Land and identity politics in Israel/Palestine. Philadelphia, PA: University of Pennsylvania Press. 


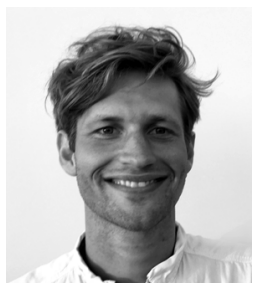

Lasse Mouritzen (1988) is graduated in Urbanism and Performance Design at Roskilde University, 2017, and is part of the art and research duo Jamboy (2013). Jamboy is working with interdisciplinary approaches, creating projects that explore aesthetic and social sides of globalization, ecology, urbanism, and new medias. Often pursuing socially grounded processes of art and research intervention they search to establish new reflection and thought on contemporary phenomena by applying a diverse, humorous and poetic imagery.

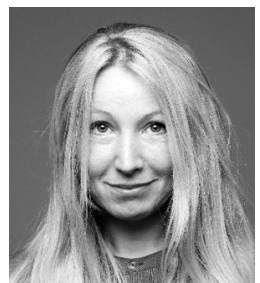

Kristine Samson is an Urbanist and Associate Professor at Performance Design and Visual Culture, Roskilde University, Denmark. She has written articles on performative and situated practices in urban space and has a particular interest in how informal practices intervene in, and potentially transform the city. Her current research project, Evental Urbanism (aie.au.dk), looks into how various social and activist practices co-produce the city. She is a board member of the Danish national research network, Take Part (projekter.au.dk/takepart). 